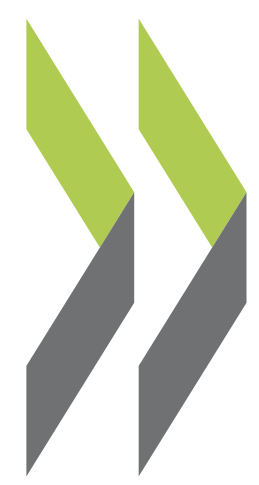

OECD Economics Department Working Papers No. 1036

\title{
Income Inequality and Poverty in Colombia - Part 1. The Role of the Labour Market
} Isabelle Joumard, Juliana Londoño Vélez 


\title{
Unclassified
}

ECO/WKP(2013)28

Organisation de Coopération et de Développement Économiques

Organisation for Economic Co-operation and Development

27-Mar-2013

ECONOMICS DEPARTMENT

English - Or. English

\begin{abstract}
INCOME INEQUALITY AND POVERTY IN COLOMBIA
PART 1. THE ROLE OF THE LABOUR MARKET
\end{abstract}

ECONOMICS DEPARTMENT WORKING PAPERS No. 1036

By Isabelle Joumard and Juliana Londoño Vélez

All Economics Department Working Papers are available through OECD's Internet Website at http://www.oecd.org/eco/Workingpapers

JT03337110

Complete document available on OLIS in its original format

This document and any map included herein are without prejudice to the status of or sovereignty over any territory, to the delimitation of international frontiers and boundaries and to the name of any territory, city or area. 


\section{Abstract/Résumé \\ Income inequality and poverty in Colombia \\ Part 1. The role of the labour market}

Income inequality in Colombia has declined since the early 2000s but remains very high by international standards. Income dispersion largely originates from the labour market, which is characterised by a still high unemployment rate, a pervasive informal sector and a wide wage dispersion reflecting a large education premium for those with higher education. Reducing income inequality is a key government objective and this requires improving the performance of the labour market. Raising educational outcomes for all and enhancing training programmes would help improve labour supply and productivity. Formal job creation however remains heavily constrained by restrictive labour market regulations, in particular very substantial non-wage labour costs and a minimum wage which is high compared to average incomes. The 2012 tax reform reduces non-wage labour costs but more decisive steps are needed to create the right conditions and incentives to boost formal employment.

JEL classification codes: H23; H52; I24; I3; I32; J16; J2; J3; O17; O5.

Keywords: Colombia; inequality; poverty; informal economy; labour taxes; education; gender discrimination.

This working paper relates to the 2013 OECD Economic Assessment of Colombia. (www.oecd.org/eco/surveys/Colombia).

\section{$* * * * * * * * * * * * * * * * * * * * * * * * * * * * * * * * * * * * * * * *$ \\ Inégalités de revenu et pauvreté en Colombie}

Partie 1. Le role du marché de travail

Les inégalités de revenu se sont atténuées depuis le début des années 2000 mais elles restent beaucoup plus fortes que dans la plupart des autres pays. La situation sur le marché du travail explique dans une large mesure ces inégalités, avec un taux de chômage qui reste élevé, un vaste secteur informel et d'amples écarts de salaires révélant un très net avantage pour ceux qui ont fait des études supérieures. La réduction des inégalités de revenu est un objectif important du gouvernement. Pour l'atteindre, il est nécessaire d'améliorer les performances du marché du travail. Réformer le système éducatif pour garantir un meilleur niveau de connaissances pour tous et améliorer la formation professionnelle contribueraient à améliorer l'offre de main d'œuvre et la productivité. La création d'emplois dans le secteur formel reste néanmoins fortement entravée par des réglementations du travail restrictives, en particulier des coûts non-salariaux particulièrement importants et un salaire minimum qui est élevé par rapport aux revenus moyens. La réforme fiscale de 2012 réduit les coûts non-salariaux mais des mesures plus ambitieuses sont nécessaires pour créer des conditions and incitations plus favorables à la création d'emplois dans le secteur formel.

Classification JEL ; H23 ; H52 ; I24 ; I3 ; I32 ; J16 ; J2, J3 ; O17 ; O5.

Mots-clés : Colombie ; inégalités ; pauvreté ; économie informelle; impôts sur le travail ; éducation; discrimination des femmes.

Ce document de travail se rapporte à l'Étude économique de l'OCDE de Colombie 2013 (www.oecd.org/eco/etudes/Colombie). 


\section{TABLE OF CONTENTS}

\section{INCOME INEQUALITY AND POVERTY IN COLOMBIA}

PART 1. THE ROLE OF THE LABOUR MARKET ........................................................................ 5

Setting the scene: income inequality and poverty are very high by international standards .................... 5

Political violence has contributed to poverty .......................................................................... 8

Inequality in labour earnings is extremely high by international standards .................................... 8

High labour costs contribute to a high unemployment rate and a large informal sector ..................... 9

Labour market reforms can promote employment in the formal sector ..................................... 17

Education: low quality and unequal access boost inequality in labour earnings ............................. 19

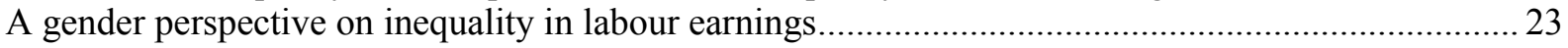

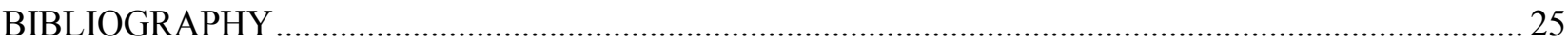

\section{Tables}

1. Social security contribution rates in 1992,2011 and as foreseen by the 2012 tax reform proposal .... 15

\section{Figures}

1. Poverty and income inequality: recent trends and international perspective ...............................6 6

2. Inequality in household labour income is very high ......................................................... 8

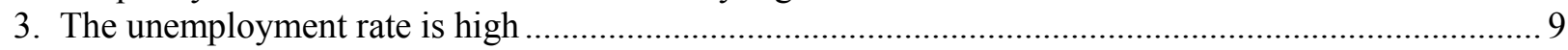

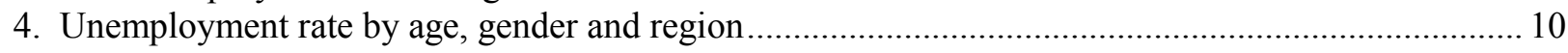

5. The degree of informality varies over time and across population groups................................... 10

6. The degree of informality varies across definitions ............................................................. 11

7. Income gap between formal and informal workers with the same education level......................... 12

8. The minimum wage has increased steadily in real terms since the late 1990 s.............................. 13

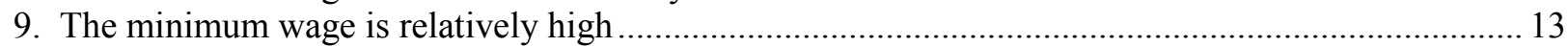

10. Minimum, average and median incomes and informality rate by region ................................... 14

11. Non-wage labour costs are high by international standards ............................................. 16

12. Education enrolment rates in Colombia, selected Latin American countries and the OECD ...........20

13. Wage gaps by education level in selected Latin American countries .........................................20

14. Net enrolment rates by income quintile and area ..............................................................2 21

15. Colombia spends more on education but gets less in return than many other countries ..................21

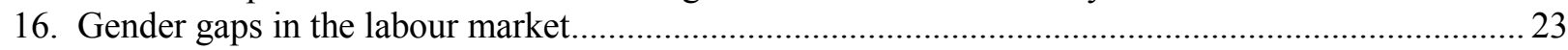

\section{Boxes}

Box 1. Poverty: measures, incidence and recent developments ............................................... 7

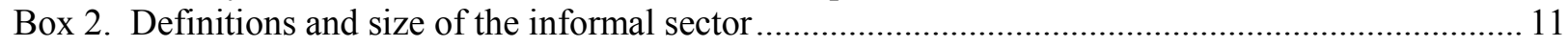

Box 3. The 2010 Formalisation and Job Creation Law ........................................................ 18

Box 4. Policy recommendations to reduce labour income inequality .........................................24 


\section{ECO/WKP(2013)28}

The statistical data for Israel are supplied by and under the responsibility of the relevant Israeli authorities. The use of such data by the OECD is without prejudice to the status of the Golan Heights, East Jerusalem and Israeli settlements in the West Bank under the terms of international law. 


\title{
INCOME INEQUALITY AND POVERTY IN COLOMBIA PART 1. THE ROLE OF THE LABOUR MARKET
}

\author{
By Isabelle Joumard and Juliana Londoño Vélez ${ }^{1}$
}

\section{Setting the scene: income inequality and poverty are very high by international standards}

Economic growth has helped secure a considerable drop in absolute poverty, measured in monetary or broader terms (Box 1). However, declines in disposable income inequality and relative poverty have been more modest. Income inequality and poverty, measured both in relative and absolute terms, remain extremely high by OECD standards (Figure 1). Reducing them is one of the government's priorities. After discussing basic poverty and inequality trends, this paper shows that income inequality largely originates from the labour market and highlights the factors driving it: a still high unemployment rate, a very large informal sector and a wide wage dispersion in the formal sector. ${ }^{2}$

1. Isabelle Joumard is a Senior Economist in the OECD Economics Department and Juliana Londoño Vélez was working as a consultant for the OECD Economics Department at the time of writing. This paper is based on the OECD Economic Assessment of Colombia prepared under the responsibility of the Economic and Development Review Committee and published in January 2013. The authors would like to thank Andrew Dean, Robert Ford, Piritta Sorsa, Peter Hoeller, Sebastian Nietto-Parra and members of the Colombian Delegation for their useful comments and suggestions, Chantal Nicq and Valéry Dugain for statistical assistance and Deirdre Claassen for her editorial support.

2. In a companion paper, Joumard and Londoño (2013) focus on the redistributive impact of the tax and transfer system in Colombia. 
Figure 1. Poverty and income inequality: recent trends and international perspective

\section{A. Colombia is a very unequal country ${ }^{1}$}

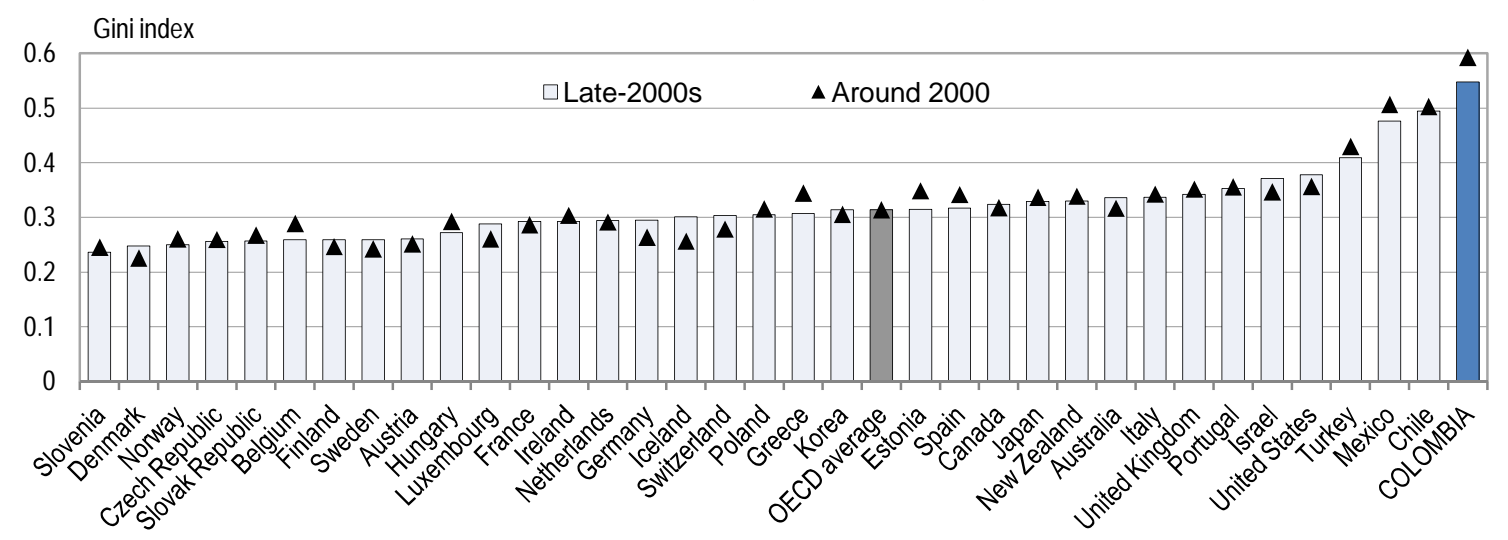

B. Relative poverty remains extremely high ${ }^{2}$

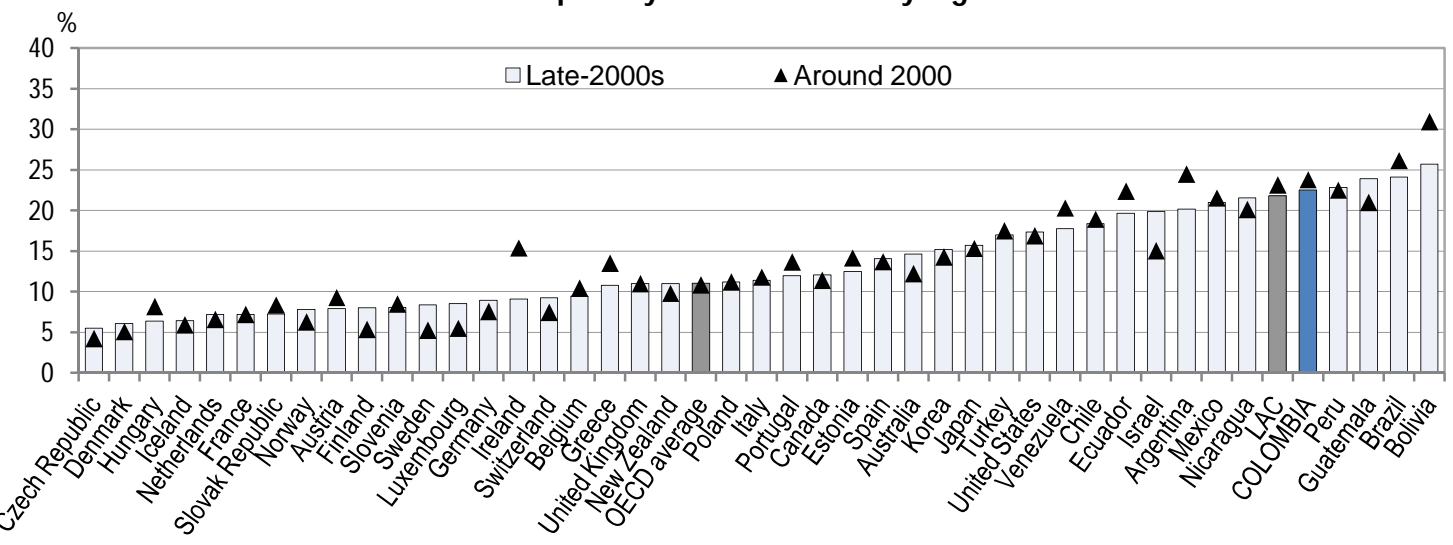

C. Monetary poverty and extreme poverty have declined ${ }^{3}$

D. Multidimensional poverty in rural areas remains high $^{3}$
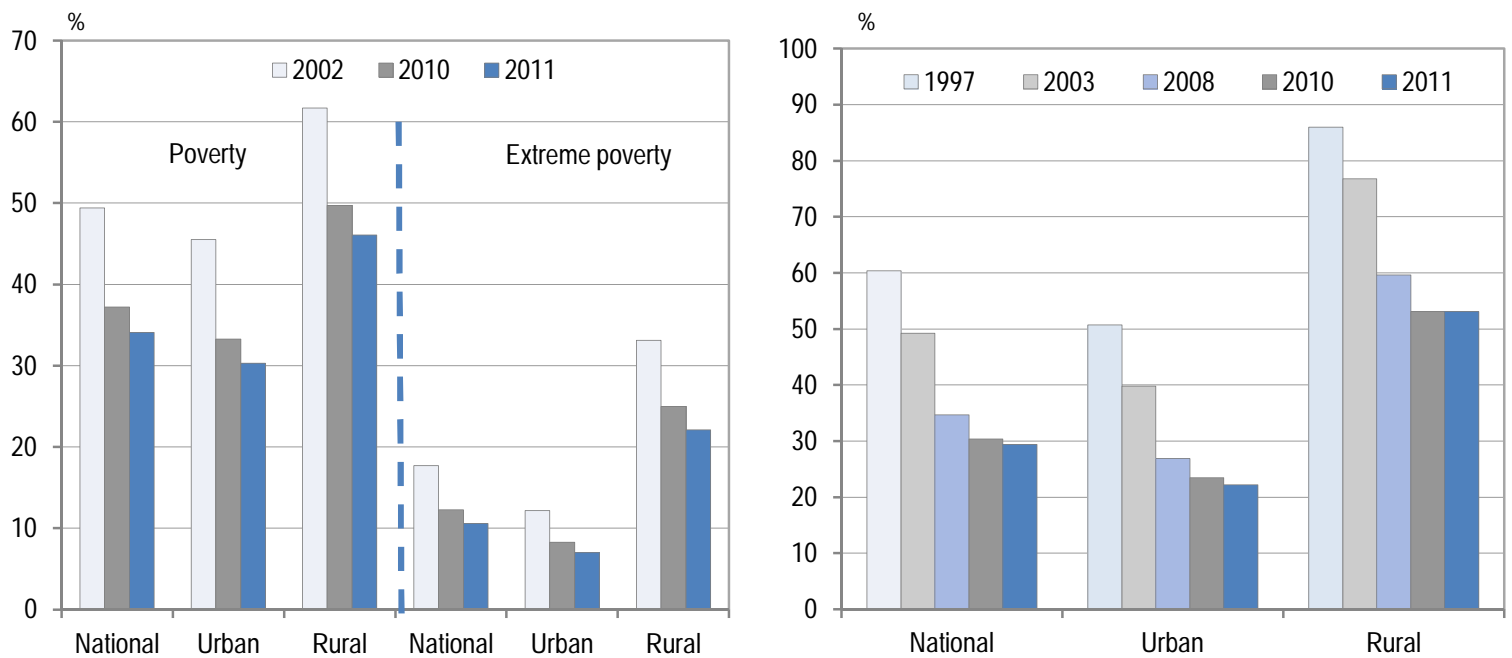

1. Gini index of household disposable income (market income after taxes and transfers), total population.

2. Relative poverty rates after taxes and transfers (threshold of $50 \%$ of the median income).

3. Monetary and multidimensional poverty are measured in absolute terms. The data show poverty incidence, as a share of total population. For multidimensional poverty, the dimensions covered are described in Box 1.1.

Source: OECD; SEDLAC; DANE, calculations based on GEIH; DNP. 


\section{Box 1. Poverty: measures, incidence and recent developments}

Poverty reduction is one of the three pillars of the current government's National Development Plan 2010-14 "Prosperity for All". To monitor poverty, evaluate public policies and assess progress in reaching the Millennium Development Goals, the government has developed improved measures of poverty. Indicators of monetary poverty and multidimensional poverty are the most important.

\section{Alternative poverty measures across OECD countries and in Colombia}

The relative merits of alternative poverty measures have been debated over the past fifty years. Poverty can be measured in absolute terms - a cut-off income line below which individuals are not able to afford a bundle of predefined basic goods - or in relative terms - with the relative poverty line defined as a percentage (usually 50 or $60 \%$ ) of median income. In addition, Sen (1983) argues that the right approach for assessing the standard of living is to focus not on basic commodities or utility but on capabilities or functionings. In OECD countries, a consensus has slowly emerged favouring the use of relative poverty measures, the United States being a notable exception (Pisu, 2012). In Colombia, the government has developed various poverty measures which help in understanding and addressing poverty, with a focus on absolute poverty and on multidimensional deprivation, which is close to Sen's approach.

\section{Recent efforts to better measure poverty in Colombia}

In 2011, Colombia adopted a new methodology to measure monetary poverty. Recently, new statistics establishing poverty and extreme poverty lines have been published. An individual is considered "poor", if he/she lacks the income required to cover a basic family food basket and other basic needs (e.g. health care expenses, education and clothing), and as "extremely poor" if he/she lacks the income to consume a minimum number of calories. The method is as follows. First, current per capita expenditure is computed, adjusted by a spatial price deflator to account for regional differences in the cost of the family basket. Households are then ordered by this measure and an iterative method is applied to select the reference population (percentiles 30 to 59). This defines the basic family consumption basket. The extreme poverty line is obtained following a normative adjustment to the minimum calorific needs. The poverty incidence is computed using a methodology developed by ECLAC for all Latin American countries to enhance the comparability of poverty measures across the region. This new methodology offers an up-to-date and more precise measure that allows for better comparability with the measures of other Latin American countries. Its advantages include updating continually consumption habits and using a better measure of income.

In Colombia, official statistics show that absolute poverty fell sharply from $49 \%$ in 2002 to $34 \%$ in 2011 (see Figure 1, Panel C). Extreme poverty also decreased, dropping from $18 \%$ to $11 \%$ over the same period. In spite of these remarkable improvements, rural poverty remains more than twice the urban rate. The government aims to reduce the poverty rate to $32 \%$ and the extreme poverty rate to $9.5 \%$ by 2014 .

Income, however, provides only a partial measure of poverty and individual wellbeing (Stiglitz et al., 2009). In an effort to go beyond income, the Colombian government adopted the Oxford multidimensional indicator of poverty in 2011. The following 5 dimensions and 15 variables are covered by the National Planning Department (DNP): (i) household educational background (e.g. educational attainment, illiteracy); (ii) childhood and youth characteristics (e.g. school attendance, repetition, access to early childhood services, child labour); (iii) employment (e.g. long-term unemployment, formal labour); (iv) health (e.g. health insurance, access to health care services conditional on need); and $(v)$ access to public services and dwelling conditions (e.g. access to treated water, sewage disposal, quality of floor and exterior walls, and overcrowding). An individual is considered poor if deprived of at least $33 \%$ of these 15 variables, taking into account their relative weights. The indicator portrays the incidence, intensity, severity and nature of deprivation. This poverty rate shrank by half, from $60 \%$ in 1997 to $29 \%$ in 2011 (Figure 1, Panel D), mainly thanks to wider health care coverage, increased school attendance among 6-16 year-olds, better access to early childhood services and reduced long-term unemployment. The rural/urban gap is higher for the multidimensional than the income approach, partly reflecting the critical lack of infrastructure (in particular water provision and sewage), low education achievement and the prevalence of informal employment in rural areas. In 2011, 300000 people moved out of multi-dimensional poverty and the government aims at reducing the incidence of poverty further from $29 \%$ to $22.5 \%$ by 2014 . 


\section{Political violence has contributed to poverty}

Political violence, both from the guerillas (especially FARC, the Revolutionary Armed Forces of Colombia) and former paramilitary groups, has predominantly affected rural areas and contributed to poverty. The persistent risk of expropriation has reduced investment incentives and thus trapped rural households into low productivity activities and poverty. Political violence has also led to a massive displacement of people -3.7 millions (8\% of the total population) over the period 1997-2011 (Acción Social, 2012). These people, mostly peasants, have lost their land and income - asset losses represented 3\% of GDP (Ibáñez and Velásquez, 2009).

Forced to move to large cities, displaced people face tremendous difficulties to find a job since their qualifications and education level do not match demand for labour in urban areas (Ibañez and Moya, 2009a and 2009b). The vast majority of displaced people thus suffer from poverty (Fernández et al., 2011). In $2008,98 \%$ of them lived below the poverty line and $74 \%$ below the extreme poverty line (Garay, 2008). While policies targeting the displaced population have long been scant, the government is providing increasing support through targeted cash and in-kind transfers (in particular education and health). The 2011 Land Restitution Law is a cornerstone in this regard, but will have a high fiscal cost (COP 54 billion over the period $2012-2021$; or $8.9 \%$ of 2011 GDP).

\section{Inequality in labour earnings is extremely high by international standards}

Income inequality in Colombia, as in OECD and Latin American countries, largely originates from the labour market (Hoeller et al., 2012; López-Calva and Lustig, 2010). Although capital income is generally more skewed than labour income, it is not a strong determinant as its share in total market income is modest - around 7\% in the OECD on average. In Colombia, inequality in labour earnings is high by OECD standards, and above most LACs (Figure 2). Household survey data compiled by SEDLAC suggest that in 2010 the top $10 \%$ richest households captured more than $40 \%$ of total labour earnings. Inequality in labour earnings reflects three main factors. First, the unemployment rate, at $11 \%$ in 2011 , remains high by OECD and Latin American standards. Second, a large share of people is employed in the informal sector, and the income of a majority of them is well below the minimum wage. Third, the wage dispersion is very wide among those working, reflecting a high education and skill premium. And many of those employed (about one third in 2012) also reported being under-employed.

Figure 2. Inequality in household labour income is very high

2010 , or latest available year

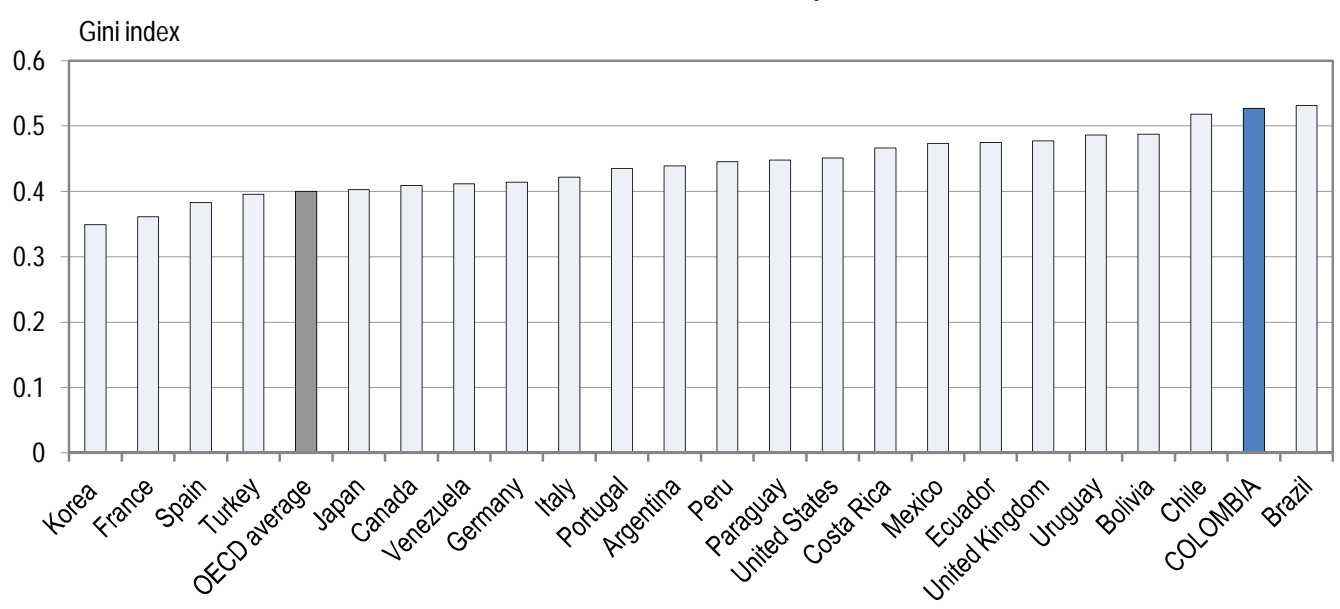

Note: Gini index of household labour income (including informal employment) for the total population.

Source: Socio-Economic Database for Latin America and the Caribbean, SEDLAC (CEDLAS and The World Bank). OECD Income Distribution database. 


\section{High labour costs contribute to a high unemployment rate and a large informal sector}

The combination of a relatively high and uniform minimum wage and high non-wage costs hurts employment prospects in the formal sector for those with low productivity, in particular the young, the low-qualified and people living in remote areas. As corroborated by many empirical studies (see for instance Mondragón-Vélez et al., 2010; Sánchez Torres and Alvarez Vos, 2011; and Santamaría et al., 2009), high labour costs in the formal sector are reflected in a large number of people working in informal employment and a rather high unemployment rate, which both exacerbate income inequality. In particular, Mondragón-Vélez et al. (2010) argue that the increases in non-wage labour costs and in the minimum wage between the 1990s and 2006 have both excluded low skilled workers from the formal labour market and triggered a move from the formal to the informal labour market, increasing the relative size of the latter.

\section{Unemployment and informal employment dominate, though their incidence differs across groups}

The unemployment rate has declined steadily since the early 2000s and employment creation has been vigorous since 2010 . However, at $10.8 \%$ in 2011 , the unemployment rate was well above the OECD average (Figure 3). In addition, the majority of those working are employed in informal and lowproductivity activities, and a third of the employed declare being under-employed. Women and the young are particularly exposed to the risk of unemployment ( $27 \%$ for $14-26$ year old women in 2011 ), as well as those living in urban areas (Figure 4).

Figure 3. The unemployment rate is high 2011 or latest available year $^{1}$

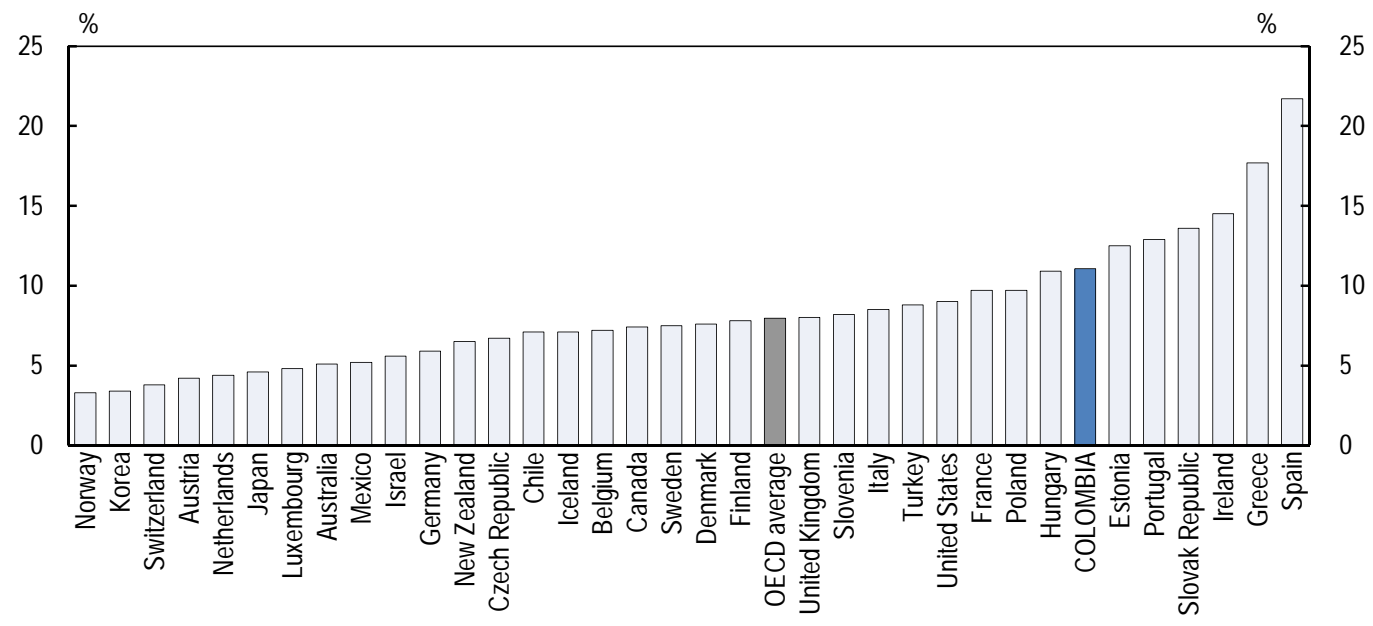

1. 2009 for Brazil, 2010 for Russia.

Source: OECD Employment Outlook, 2012; DANE. 
Figure 4. Unemployment rate by age, gender and region

2011

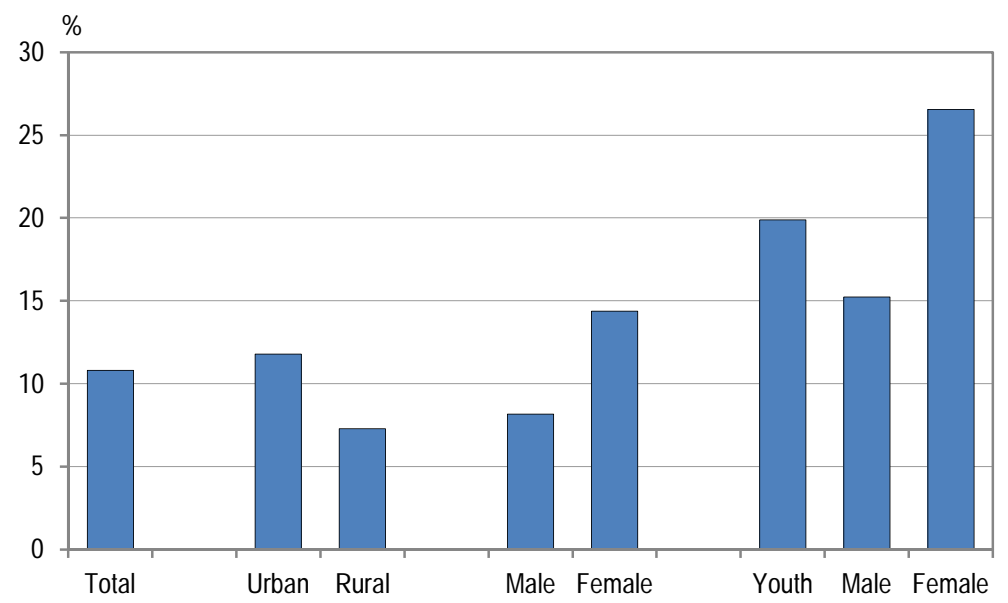

Note: The youth are defined as those aged between 14 and 26 .

Source: DANE.

While the informal sector can be measured in various ways (Box 2), all measures suggest that it is very large, even compared to other Latin American countries (Bernal, 2009; ILO, 2011). Informality has increased rapidly over the 1990s and affects the less educated the most, in particular the young with little work experience and older workers (Figure 5). Still, more than a fourth of those with a university degree are informal workers - they do not contribute to the mandatory pension system. This suggests that informality may not systematically be forced by employers nor related to exclusion from the formal sector, but rather that it may be a worker's decision, e.g. to minimise tax payments. The informality rate, as measured by firm size, is also much higher in rural than in urban areas. This coincides with a low productivity level in rural areas.

Figure 5. The degree of informality varies over time and across population groups

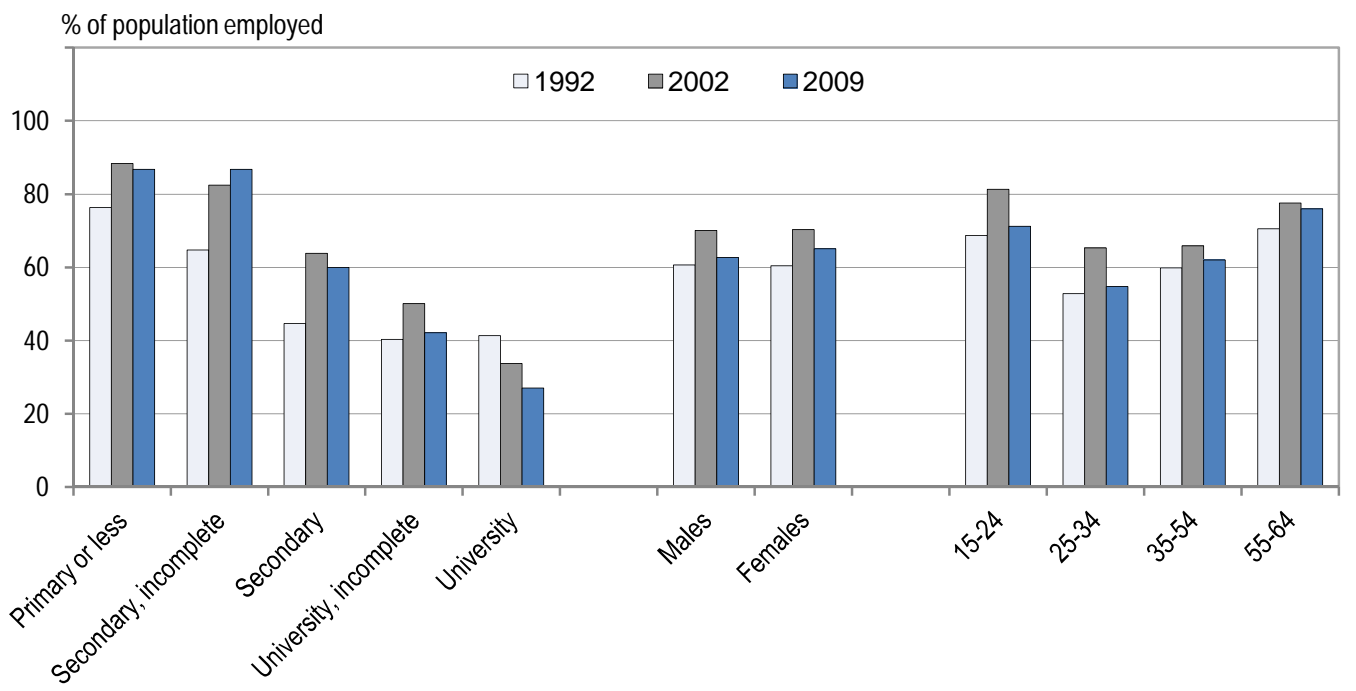

Note: Informality is defined here as the percentage of employees not contributing to the pension scheme.

Source: Sanchez Torres and Alvarez Vos (2011); DANE. 


\section{Box 2. Definitions and size of the informal sector}

The Statistics Office (DANE) uses a definition of the informal sector based on firm size and occupation - the informal sector comprises the workers and owners of firms employing less than 5 persons, as well as unpaid family members and housekeepers. According to this definition, about $50 \%$ of the employed population was in the informal sector in early 2012, a level which has been broadly stable since the late 1990s (Figure 6).

Defining informal workers as those who contribute to neither the health nor the pension systems suggests a $70 \%$ informality rate, although informality levels are lower when considering the health and pension systems separately.

Figure 6 . The degree of informality varies across definitions

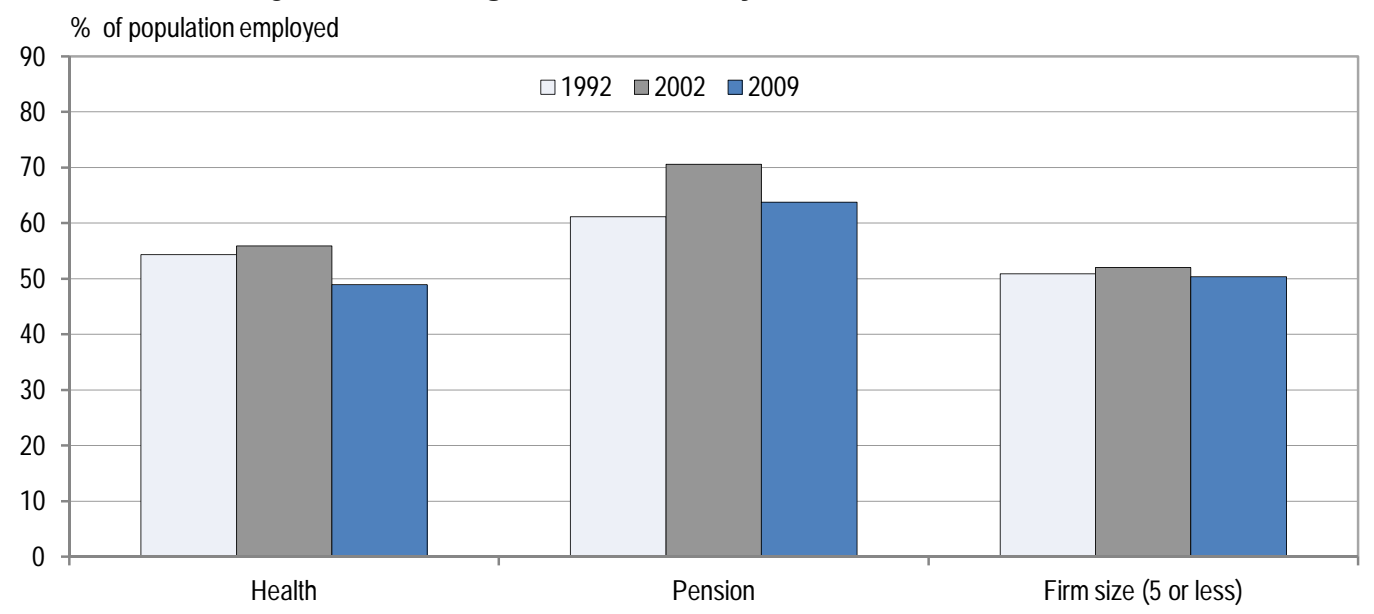

Notes: $\quad$ The health/pension columns relate to the share of those employed, but not contributing to the health/pension insurance schemes. The firm size column corresponds to the share of the population employed in firms of five or less persons. For this column data are for 2007, 2009 and 2012 (not 1992, 2002 and 2009).

Source: Sanchez Torres and Alvarez Vos (2011); DANE.

Those in the informal sector earn less, exacerbating income inequality

The high rate of informal work is a key driver of income inequality since informal workers often suffer from poor working conditions and lack social safety nets, which puts them at a high risk of poverty when they lose their job or retire. More than two-thirds of informal workers earn less than the minimum wage. The ratio of the compensation in the formal to the informal sector increased steadily during the 1990s, from 1.4 in 1992 to almost 2.2 in 2002. It has decreased slightly since then, but remains high (Sánchez Torres and Alvarez Vos, 2011). While this gap partly reflects a composition effect - the formal sector employs more qualified persons - those working in the informal sector are also paid less for the same level of qualification, and the gap is the highest for the less educated (Figure 7). 
Figure 7. Income gap between formal and informal workers with the same education level Ratio of compensation in the formal to the informal sector

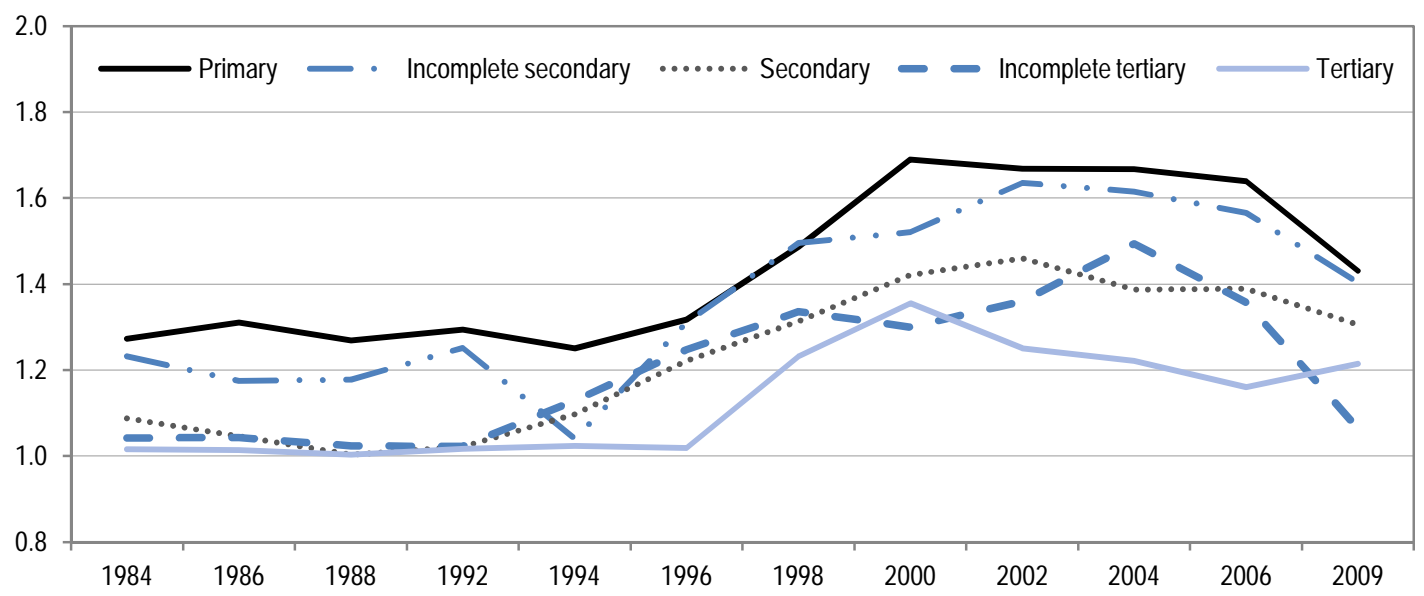

Note: The term "tertiary education" encompasses all the post-secondary education, which Colombians call "educación superior". Source: Sanchez and Alvarez (2011) based on national household surveys by Colombia's National Statistics Department (DANE).

\section{A high minimum wage contributes to informality}

The impact of the minimum wage on employment has been much debated in the empirical literature, but the balance of evidence suggests that, if too high, minimum wages exclude those who are the least productive or experienced from the formal labour market (Bassanini and Duval, 2006; Koske et al., 2012). In Colombia, the yearly minimum wage is adjusted by a centralised bargaining process between representatives of trade unions, businesses and the government. By law, the minimum wage should be raised to reflect the central bank inflation target for the year plus productivity changes. Since 1999, the Constitution further stipulates that yearly adjustments in the minimum wage should at least match past year's inflation. This institutional set-up has generated upward pressures, with the minimum wage increasing by $21 \%$ in real terms between 1998 and 2010 (Figure 8), i.e. well above productivity developments (Hofstetter, 2006). In 2011, the minimum wage stood at $71 \%$ of the average wage, one of the highest in the world, up from 58\% in 2007 (Figure 9). The minimum wage is particularly binding in the poorest, low-productivity regions, where its level is above median and average income and where informality is also most prevalent (Figure 10). 
Figure 8 . The minimum wage has increased steadily in real terms since the late 1990s

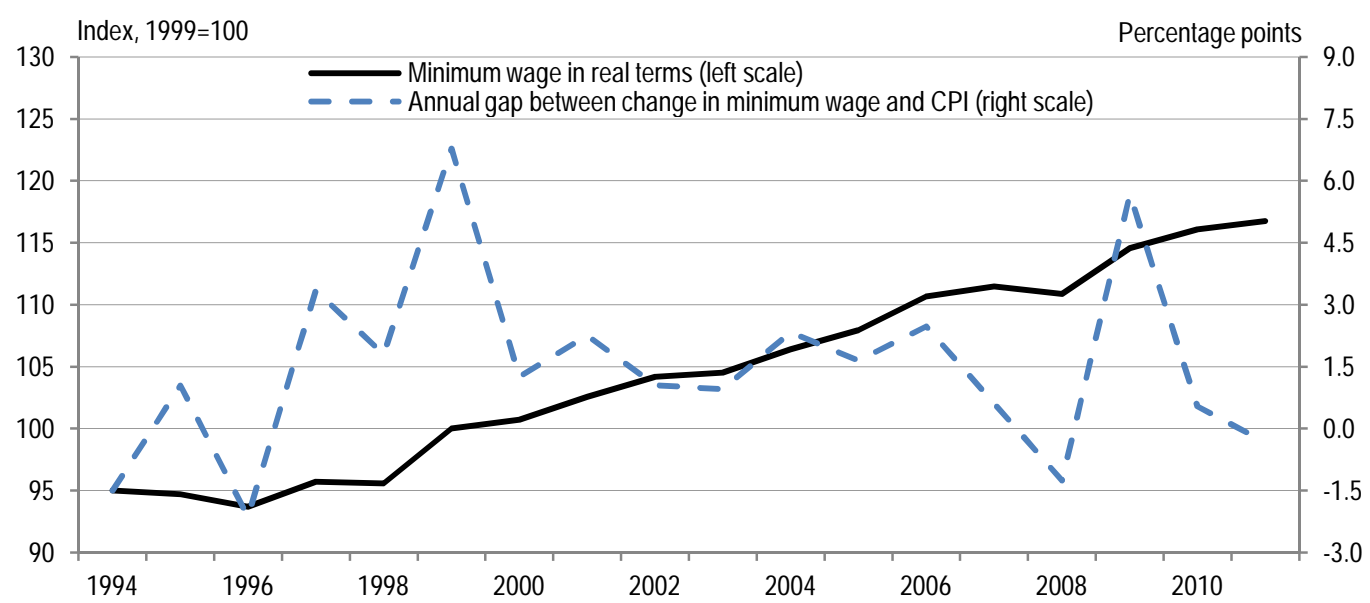

Note: Monthly minimum wage in the urban sector, excluding transport subsidy.

Source: OECD Secretariat calculations based on Colombia's National Statistics Department (DANE) and World Bank data.

Figure 9. The minimum wage is relatively high

Ratio of minimum wage to average wage, 2011 of latest available year

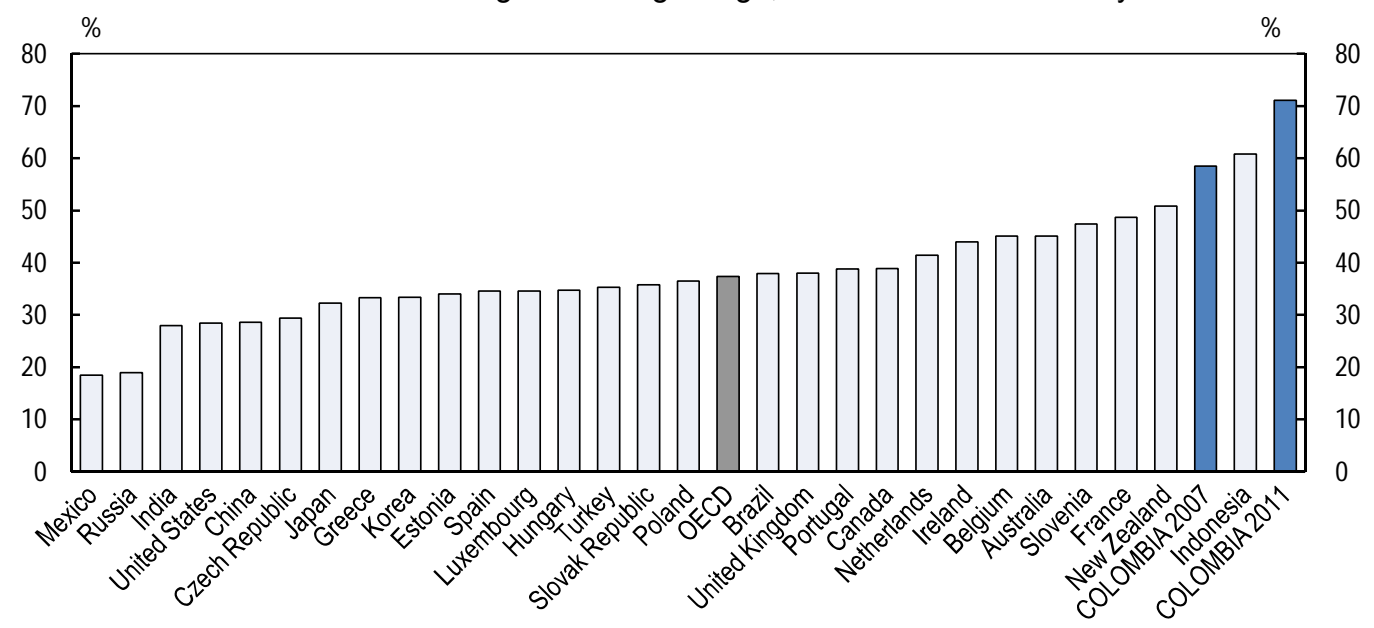

Note: Missing countries do not have a statutory minimum wage except for Chile and Israel for which data are not available. Data are for 2011 except for Brazil, China, India, and Russia for which they are for 2010. The average wage for Colombia covers both formal and informal sectors.

Source: Employment Outlook database and Going for Growth, OECD 2012; OECD estimates. 
Figure 10. Minimum, average and median incomes and informality rate by region

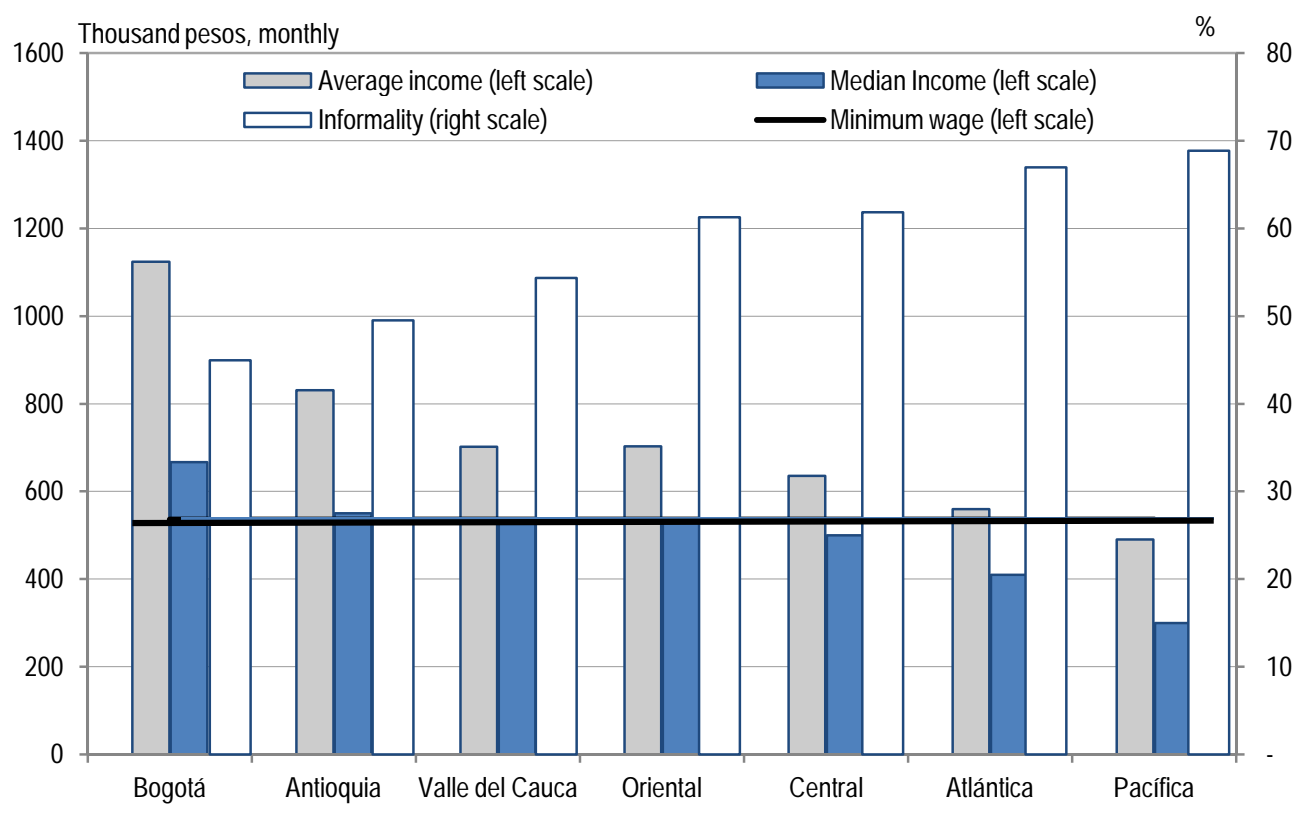

Source: DANE

High non-wage labour costs also deter the creation of formal jobs

Very high non-wage labour costs compound the effects of the high minimum wage on formal employment. Demands for more social spending have been building up since the early 1990s and social protection is financed mostly through social security contributions (as opposed to general taxation). As a result, non-wage labour costs have risen substantially. Social security contribution rates for health and pensions have increased by 15 percentage points, from $14 \%$ to $29 \%$, since the early 1990 s (Table 1 ). Overall, non-wage labour costs (NWLCs), at $45 \%$ of total labour costs for the average worker in 2011, are much higher than in most OECD countries, and compare even less favourably with other LACs and emerging economies (Figure 11). In addition, since the minimum contribution is set with reference to the full-time minimum wage, NWLCs are significantly higher for part-time work. 
ECO/WKP(2013)28

Table 1. Social security contribution rates in 1992, 2011 and as foreseen by the 2012 tax reform proposal For the worker with average wage

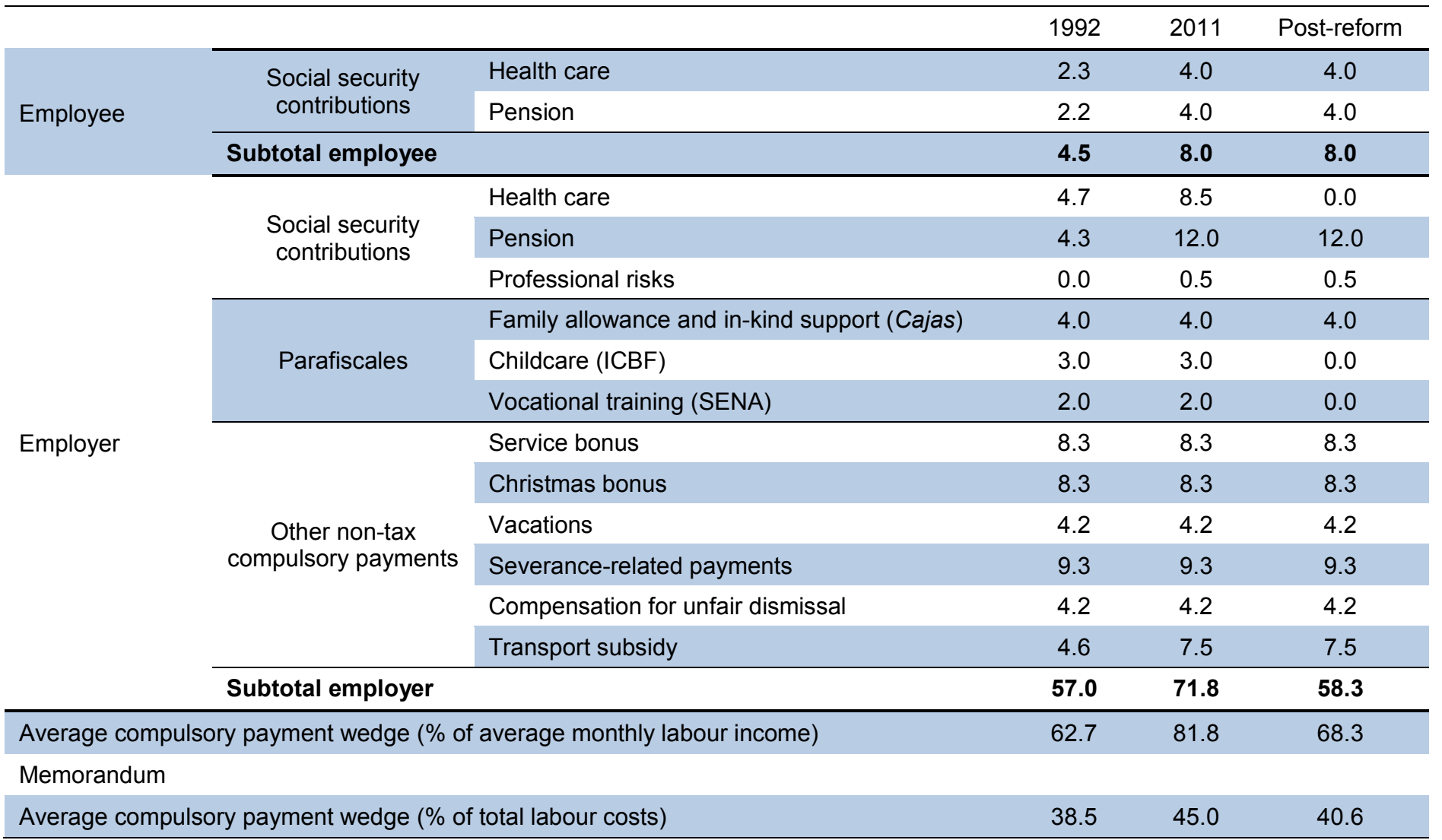

Note: The work uniform subsidy mandated by law is not included. Given that the average wage is less than 4 times the minimum wage for the years studied, the employee pension contribution rate does not include the surcharge. The contribution for professional risk depends on job characteristics, but $0.52 \%$ is the most common rate (IMF, 2011). The Christmas bonus is mandatory for all public-sector workers, but voluntary for those in the private sector. The amount given to the employee for unjustified dismissals depends on the type of contract (indefinite or definite) and the time employed. The rate used here corresponds to the minimum compensation, equal to 15 work days. The transport subsidy is a fixed amount that is only given to employees earning less than twice the minimum wage, and to workers that live more than 1 kilometer away from their workplace. The table expresses this amount as a percentage of average monthly labour income. For bonuses and severance-related payments, contribution rates apply to both the take-home pay and the transport subsidy. This explains why the average compulsory payment wedge is not the sum of the shares paid by employers and employees.

Source: OECD Secretariat. 
Figure 11. Non-wage labour costs are high by international standards As per cent of labour costs, $2011^{1}$

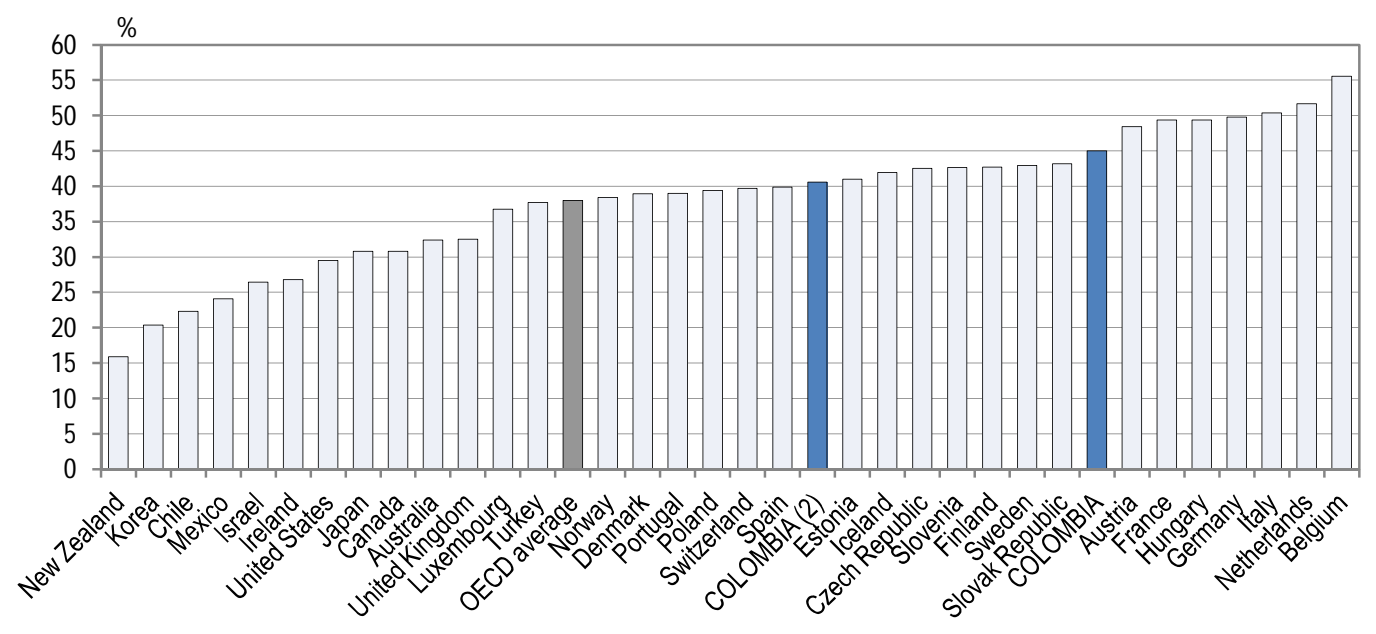

1. Non-wage labour costs for a single individual without children at the income level of the average worker. Non-wage labour costs include tax and non-tax compulsory payments, that is, both requited and unrequited compulsory payments to privatelymanaged funds, welfare agencies or social insurance schemes outside general government and public enterprises. The 2011 average earnings data for Greece were not available.

2. Colombia after the tax reform proposal, as presented in Table 1.

Source: OECD Tax Database; OECD estimates.

\section{The benefits of paying social security contributions are low}

Some social contributions are earmarked for benefits associated with the labour market status, in particular pension and unemployment benefits, which can be seen as part of labour compensation. Others, however, finance benefits available to all citizens, whether they contribute or not (e.g. training services and child care), or have a redistributive objective. Payments and benefits are thus disconnected, which reduces incentives to pay into the system.

The reliance on social security contributions to finance universal health care creates strong incentives to remain in the informal sector. Universal health care coverage has been achieved gradually since the 1993 health reform. Since then, two health systems have co-existed. Formal sector employees pay social contributions, and are thus part of the "contributory regime", which give them and their direct dependents (spouse, children or one parent) access to a range of health services and drugs known as the Plan Obligatorio de Salud (POS). The "subsidised regime", financed by a $1 \%$ transfer from the contributory regime and local and central government funds, gives poor households (i.e. Sisbén 1 and 2) free access to a package of services and drugs known as the Plan Obligatorio de Salud Subsidiado (POSS).

While the POSS has long been less generous than the POS, the two packages have gradually converged, following a 2008 Constitutional Court ruling. Since June 2012, the two health packages have become similar, thus reducing incentives to pay health care contributions even further. In fact, the subsidised regime is more generous in terms of people covered - every member in an eligible household, regardless of the relationship with the household head, gets access to the POSS. Members of large families thus face stronger incentives to remain in the informal sector. Also, one may lose health coverage by losing a formal job, without being able to quickly regain access to the subsidised health system. Moreover, given 
that workers eligible for the subsidised regime (i.e. the poor) are also eligible for an array of social programmes (e.g. Familias en Acción), the potential loss in other benefits further dissuades workers from accepting formal jobs. Overall, Camacho et al. (2009) estimated that the 1993 law resulted in an unintended increase in informal employment - defined as the share of employees between 12 and 65 who do not contribute to health insurance through employment - by 4 percentage points. In 2012, more than half of the population was covered by the subsidised regime, up from about one third in the mid-1990s. It should be noted, however, that means-tested social benefits remain low by OECD standards. Workers' incentives to remain informal are thus limited. Social benefits may thus not be the main factor behind the high level of labour informality and unemployment.

Three so-called parafiscales (special earmarked taxes on wages) finance social assistance benefits and training programmes. The contribution rate is $9 \%$ on wages, with revenues amounting to $1.3 \%$ of GDP in 2009 (Jorratt, 2010). In addition to having a detrimental impact on job creation in the formal sector, their usefulness, effectiveness and redistributive impact are questionable. The largest parafiscal is a $4 \%$ contribution, which is collected and managed by several private entities, the Cajas de Compensación Familiar (CCF). It finances family allowances for formal sector workers who earn no more than 4 times the minimum wage. Since informal workers and the unemployed are not entitled to receive their services, they benefit the well-off most: the richest quintile receives $32 \%$ of the total, while the poorest receives only $2 \%$ (Moller, 2012). The CCFs also finance culture, tourism and commercial activities and own supermarkets, theatres, hotels and other facilities. Yet there is little evaluation of the cost-effectiveness of the services the CCFs provide (Alm and López-Castaño, 2005).

The two other parafiscales finance programmes that target those in need, but suffer from low cost-effectiveness. A $2 \%$ contribution finances traineeship programmes, in particular for young workers and displaced persons, through the Servicio Nacional de Aprendizaje (SENA). The SENA also finances assistance to firms for technological development and information systems. SENA's administrative costs are high (20\% of the total budget in 2002 according to Alm and López-Castaño, 2005). More importantly, there are few data on SENA's outcomes and available studies on the impact of SENA's services on jobs and wages question their cost-effectiveness (Saavedra and Medina, 2012). Other training programmes available may be preferable (Barrera and Corchuelo, 2003). An additional 3\% contribution finances day-care for children, school food programmes, aid to children at risk and food supplements for the elderly through the Instituto Colombiano de Bienestar Familiar (ICBF) - more than 10 million people were covered by the ICBF in 2011.

\section{Labour market reforms can promote employment in the formal sector}

Recent reforms to reduce labour costs are welcome, but are unlikely to be enough to dent informality and the associated income inequality. The 2010 Formalisation Law reduced non-wage labour costs for some categories of employees and some firms (Box 3). However, the impact of the law on job creation is difficult to assess since some firms and jobs would have been created even in the absence of the law. The law provides incentives for firms to split up and encourages a process of firm destruction/creation to take advantage of the lower labour costs, which is probably inefficient. The reduction in labour costs is estimated by Sánchez Torres and Alvarez Vos (2011) to be about $12 \%$ for an employee paid at the minimum wage. This is much less than the gap in labour costs between the formal and informal sector about $50 \%$ for those who have not completed secondary education. The Ministry of Labour is preparing an evaluation of the Formalization Law. 


\section{Box 3. The 2010 Formalisation and Job Creation Law}

The 2010 Law (Ley de Formalización y Generación de Empleo) aims at:

- Increasing formality among small firms (defined as those employing less than 50 workers and with assets less than 5000 times the minimum wage) with a target of 2.5 million jobs formalised over a 4-year period.

- Creating formal employment, with a target of 500000 jobs over a 4-year period, in particular for the young, displaced persons, people previously enrolled in illegal armed groups (i.e. guerrillas and paramilitaries), disabled persons, women over 40, and the poor.

\section{Formalisation of small enterprises}

The main benefits offered to newly created small firms registered at a Chamber of Commerce, including those that had operated in the informal sector, are as follows:

- $\quad$ Access to government support programmes, which include microcredit programmes targeted at individuals under 28 years, as well as technical training and financial support programmes.

- $\quad$ Reduced tax and social security contributions for some years. First, firms will pay only a fraction of the corporate income tax liability, which will increase gradually over time: No income tax is paid in the first two fiscal years; $25 \%$ in the third fiscal year; $50 \%$ in the fourth fiscal year; $75 \%$ in the fifth fiscal year; and $100 \%$ from the sixth fiscal year onwards. (A more generous treatment is granted to firms in the scarcely populated regions of Amazonas, Guainía and Vaupés). Firms will also be allowed to carry forward their losses, up to an additional five fiscal years. Second, firms will pay only a fraction of the parafiscales (a category of social security contributions, see above), following the same schedule as for the corporate income tax. (Again, a more generous treatment is granted to firms in the scarcely populated regions). Third, firms will be granted some relief from industry and commerce tax payments levied by sub-national governments. Fourth, the commercial registration and renovation fee will be reduced: No payment in the first year; $50 \%$ of the fee in the second year; $75 \%$ in the third year; and $100 \%$ from the fourth year onwards.

- $\quad$ Simplified administrative and legal procedures: work, commercial and other procedures will be simplified to facilitate formalisation for all firms.

\section{Employment and income tax burden of vulnerable population groups}

- $\quad$ Tax relief on income and payroll taxes will be granted to employers hiring new employees that are (i) under 28 years of age; (ii) part of the displaced population; (iii) persons in the process of reintegration; (iv) handicapped; ( $v$ ) women over 40 years that have not had a job contract in the past 12 months; or (vi) earning less than 1.5 times the minimum wage. These tax reliefs correspond to parafiscales liabilities, plus contributions to the solidarity health care fund (FOSYGA) and to the minimum pension fund. They are limited to 2 or 3 years, depending on the type of employee that is being hired.

- $\quad$ A fairer withholding income tax for independent workers: Independent workers with service contracts under a given threshold (equal to almost 14 times the minimum wage in 2012) will face the same marginal income tax rates as employees.

The tax reform plan presented in October 2012 cuts non-wage labour costs. These cuts cover most jobs, as opposed to those just recently created or formalised, and they have thus less distortive effects. Some parafiscales - those financing ICBF $(2 \%)$ and SENA $(3 \%)$ - and the employers' health care contributions $(8.5 \%)$ will be abolished for firms employing workers with monthly wages under 10 times the monthly minimum wage. By reducing contribution rates on wages by 13.5 percentage points, the reform aims at creating between 400000 and 1 million formal jobs. However, non-wage labour costs, at $41 \%$ of total labour costs, remain above the OECD average and most other LACs (see Figure 11). Promoting formal employment may thus require a more ambitious reform to reduce labour costs, in particular for low productivity workers. Moving further from social security contributions to other taxes for the financing of some public programmes (in particular health care contributions paid by employees) 
should be considered. In addition, there is a case for moving from mandatory to voluntary contributions for the commercial activities run by the Cajas de Compensación Familiar. Introducing a lower minimum wage for young people and/or in rural areas, which are characterised by lower living costs, should also be considered.

\section{Improving labour market policies}

Strengthening active and passive labour market policies would also contribute to a better performance of the labour market and help reduce income inequality. The government has launched various welcome initiatives. First, an Apprenticeship Law has been presented to Congress in November 2012 with the objective of increasing the number of persons with a trainee contract (and thus covered by labour laws and social protection) and facilitating their incorporation onto the labour market. Trainees with no university degree would be paid at $75 \%$ of the minimum wage. The proposed law would also enable companies to develop training programmes supervised by the National Training Service (SENA). Second, a Public Employment Service is being designed and implemented in order to match supply and demand for labour, with a regional view. Third, while there is no fully-fledged unemployment insurance system, the government is considering introducing a system of individual Unemployment Saving Accounts complemented with a solidarity fund.

\section{Education: low quality and unequal access boost inequality in labour earnings}

Education policies matter for reducing inequality in labour income, by raising employment and earnings prospects of those at the margin of the labour market. Empirical evidence for OECD countries suggests that raising graduation rates from upper secondary and tertiary education and increasing early childhood care and education coverage reduces income inequality (OECD, 2012a; Koske et al., 2012). Unequal access to educational services, large gaps in the quality of education between private and public schools, or persistent financial access constraints perpetuate income inequality. Experience in OECD countries suggests that education is also a key driver of social mobility (OECD, 2010). In Colombia, however, the link may be weaker (Angulo et al., 2012): while education coverage has expanded, in particular at the secondary level, the sluggish progress in upgrading education quality has hindered social mobility.

\section{Education coverage has increased but is still below the OECD and Latin American average}

Efforts have been made to increase education coverage, with a significant rise in net enrolment rates in pre-primary and secondary education (Figure 12), but more is needed. The conditional cash transfer programme Familias en Acción launched in 2001 and targeted at the poorest has contributed to spur school attendance, in particular for children between 12 and 17 and in rural areas (Attanasio et al., 2005). The drop-out rate of pupils from families with an income below the minimum wage has also decreased from $32 \%$ in 1999 to $14 \%$ in 2011. Still, few children before age 6 and after age 15 attend school. The net enrolment rate of children aged 15-17 was only $40 \%$ in 2009 . And pupils from a disadvantaged socio-economic background -i.e. Sisbén 1 - on average attend school only 5.2 years, compared with 12.7 years for pupils from richer families - i.e. Sisbén 6 (Barrera et al., 2012). 
Figure 12. Education enrolment rates in Colombia, selected Latin American countries and the OECD 2009 or latest available year

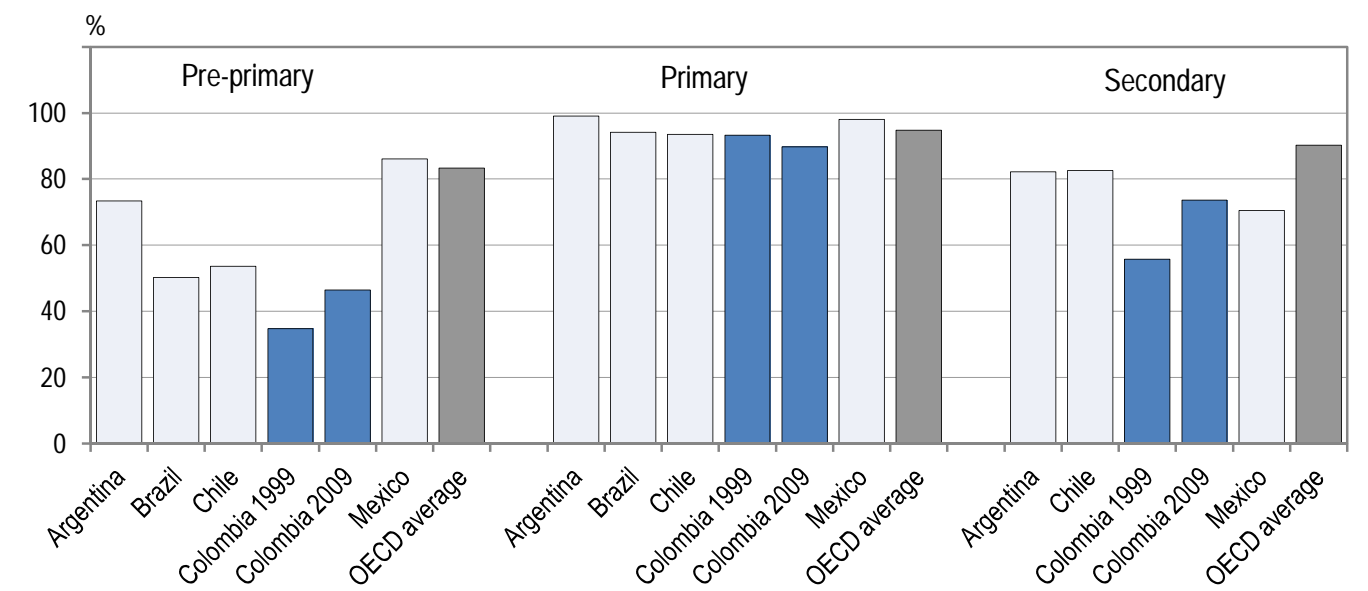

Note: The net enrolment rate is the ratio of children of ofticial school age (based on the International Standard Classification of Education 1997) who are enrolled in school, to the population of the corresponding official school age. Data on secondary enrolment rates are not available for Brazil.

Source: UNESCO Institute for Statistics database.

The most educated enjoy a very large wage premium. This could potentially encourage educational attainment, but it exacerbates income inequality. The net enrolment rate in tertiary education increased substantially from $17 \%$ in 2002 to $24 \%$ in 2010 , but is still low by OECD standards (OECD, $2012 \mathrm{~b}$ ). The limited supply of workers with tertiary education is reflected in the high wage differential at the top of the income distribution (Figure 13). As an illustration, those graduating in 2011 from university earned on average 6 times more than those with a high-school degree. In addition, while the expansion of tertiary education coverage has reached the poorest, income-related participation gaps have, if anything, widened: enrolment rates are much higher for students from high income families and for those living in urban areas (Figure 14).

Figure 13. Wage gaps by education level in selected Latin American countries 2010 or latest available year

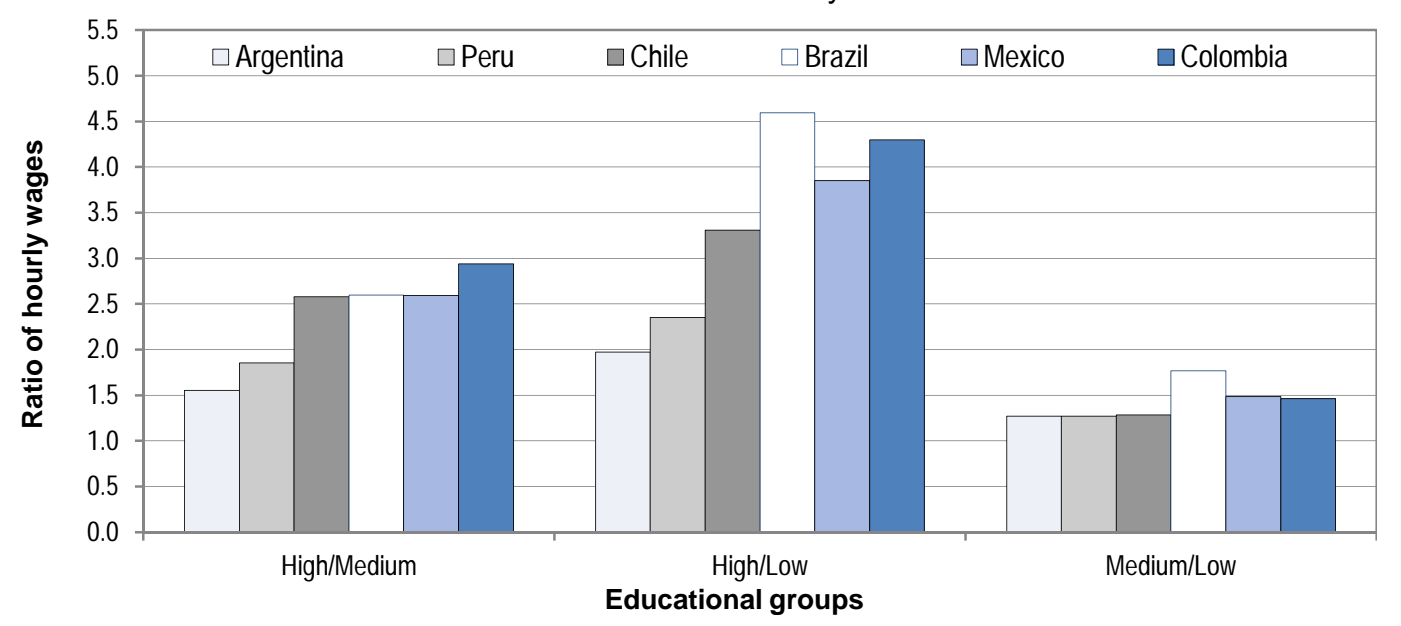

Notes: Skill group categories defined as Low have 0 to 8 years of formal education; Medium, 9 to 13 years; and High, more than 13 years.

Source: SEDLAC (CEDLAS and The World Bank). 
Figure 14. Net enrolment rates by income quintile and area

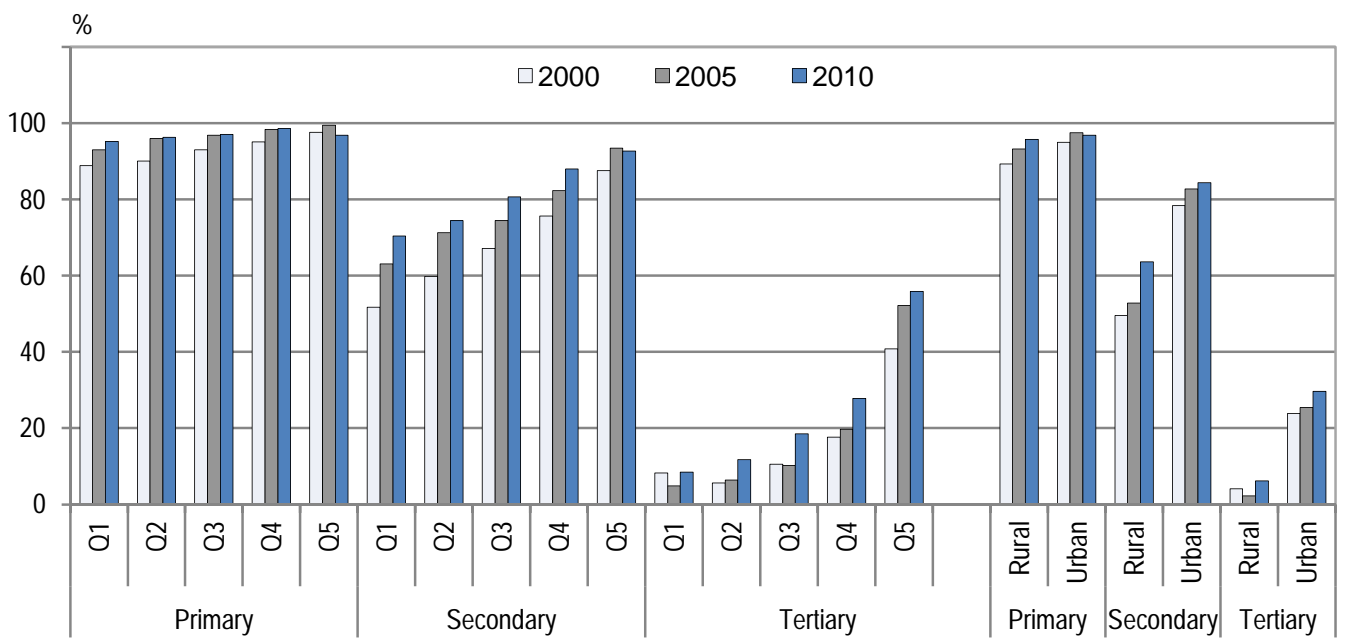

Source: SEDLAC (CEDLAS and The World Bank).

\section{Improving education quality and outcomes should become a priority}

Despite improvements, educational outcomes remain below the OECD average and that of many other emerging economies (Figure 15). The PISA survey further reveals that outcomes of children from a disadvantaged socio-economic background are particular poor. In addition, the PISA results probably overestimate Colombia's performance compared with OECD countries due to the underrepresentation of pupils from underprivileged backgrounds, who are less likely to attend school in Colombia than in OECD countries (Ferreira and Gignoux, 2011). These relatively poor educational outcomes cannot be attributed to a lack of resources: total spending on education in Colombia, at $7.6 \%$ of GDP in 2011, is above the OECD average and many other countries with a similar income per capita. The private share, at over 3\% of GDP, is much higher than the OECD average of less than $1 \%$ while about one fifth of the Colombian students, mostly from advantaged families, attend privately managed schools (i.e. about the OECD average). Raising spending efficiency should thus be a priority.

Figure 15. Colombia spends more on education but gets less in return than many other countries

A. Spending on education tends to increase with income

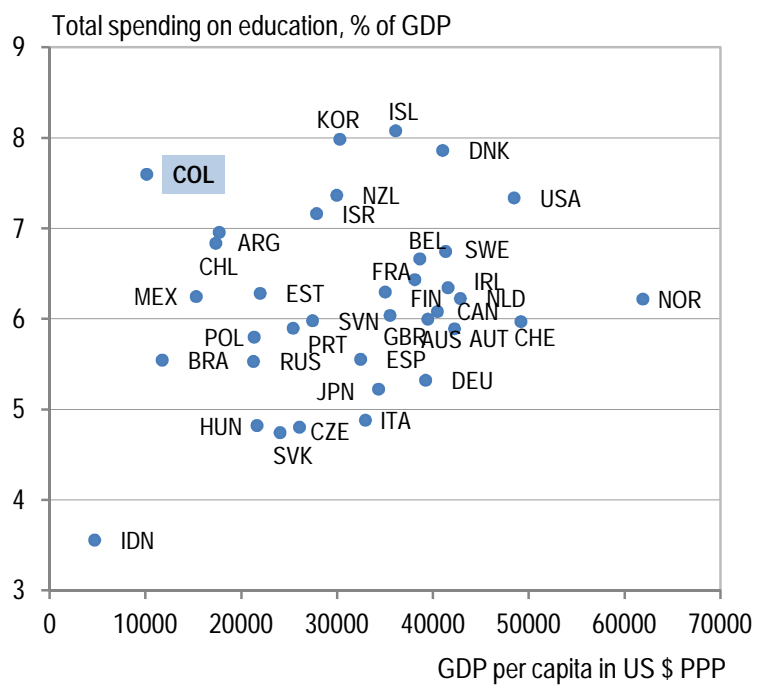

B. Education outcomes do not increase in line with spending

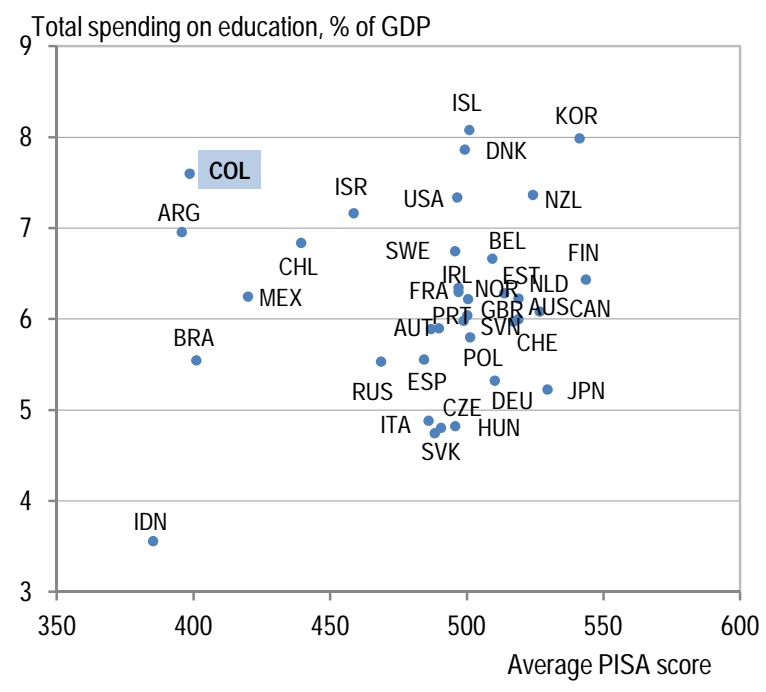

Source: Education at a Glance 2012; OECD (2011a); World Bank database. 
Various factors are affecting education outcomes. First, teaching time is low for some children since many schools operate two to three shifts per day. Less than $11 \%$ of pupils attending public schools are entitled to a full teaching day, compared with $46 \%$ for those attending private schools (Barrera et al., 2012). Since private schools cover predominantly pupils from well-off families (and more so in Colombia than in many other countries, OECD, 2012c), many pupils face a double liability of coming from a disadvantaged background and attending a lower-quality school. Second, the poor selection and training of teachers affect education quality. Students trained to become teachers often obtain very low scores, compared with other students, on cognitive tests such as Saber PRO (Barón and Bonilla, 2011). Third, despite recent reforms introducing some elements of performance-based compensation and promotion, and the possibility to fire low-performing teachers, there is still a high degree of teacher absenteeism (estimated at $10 \%$ on average, and reaching $40 \%$ in rural areas). Experience in India suggests that monitoring coupled with financial incentives based on teacher attendance can reduce teacher absence and raise educational outcomes (Duflo et al., 2012). Fourth, while schools have a large autonomy in setting school curricula and in choosing textbooks, they have virtually no autonomy in managing resources (e.g. selecting teachers).

While the responsibility for education has largely been devolved to sub-national governments, the central government has recently taken ambitious measures to improve the quality of primary education, in particular in the most deprived areas. The government is introducing a mentoring programme for teachers working in 3000 low-performing schools (about one fifth of schools). This initiative is promising and the outcomes should be evaluated in due time. Many countries - including China, Japan, New Zealand and Switzerland - offer programmes with mentoring schemes, and research shows that both new and experienced teachers profit from them (OECD, 2012c). The government is also working closely with subnational authorities, which are responsible for designing the education curricula, by providing high quality textbooks.

The government has made significant efforts to increase the coverage and improve the quality of programmes targeting children under age 5. Well-targeted and well-designed interventions can have longlasting effects by raising cognitive and socio-emotional abilities and the health of disadvantaged children (Carneiro and Heckman, 2003; Heckman, 2008). Between 2007 and 2011, about 590000 children received health care, nutrition, care and early education services. To reinforce these efforts, in 2011 the government brought forward Estrategia de Cero a Siempre, a plan that aims to benefit 1.2 million children under age 5 in 2014 at a cost of COP 5.6 trillion (US $\$ 3$ billion). As part of this strategy, interventions targeting poor households with children between 1 and 2 years of age have been recently launched. Households benefitting from Familias en Acción have received a micronutrient supplement and support to develop cognitive and language skills of children. Preliminary results suggest that the intervention improved both cognitive development and the quality of the home environment (Attanasio et al., 2012).

\section{Equity in access should be promoted further}

OECD evidence suggests that the best performing education systems are those that combine equity with quality (OECD, 2012c). In Colombia, some reforms have recently been implemented to improve equity in access to education, but more work is needed. Public primary and secondary schools are free of charge as of 2012, which should increase attendance of children from disadvantaged socioeconomic background. In addition, the formula used to allocate resources across municipalities was adjusted in 2011 to better reflect the socio-economic background of pupils (Barrera et al., 2012). Still, enrolment rates vary significantly with family income and drop-out rates in tertiary education are very high for students from low-income families (CEDE, 2009). The student support system (ICETEX) provides students with loans, which include a grant element whose amount depends on the beneficiaries' income level. The number of loans has almost tripled between 2003 and 2011. However, because of the increase in the enrolment rate, a lower proportion of students receive loans (OECD, 2012b). In addition, ICETEX is not targeting all its resources on those most in need, because of serious flaws in the way income is assessed through the Estratos system (Joumard and Londoño, 2013). 


\section{A gender perspective on inequality in labour earnings}

Female participation in the labour market has increased substantially over the past decades, reaching $53 \%$ in 2011. However, and despite the existence of a legal framework to promote gender equality and the higher average educational level of females, gender gaps in labour market outcomes are sizeable. In particular, female participation and employment rates are lower than for males. They suffer more from unemployment and those employed receive lower wages (Figure 16).

Figure 16. Gender gaps in the labour market

2011

Panel A. Females suffer more from unemployment and informality

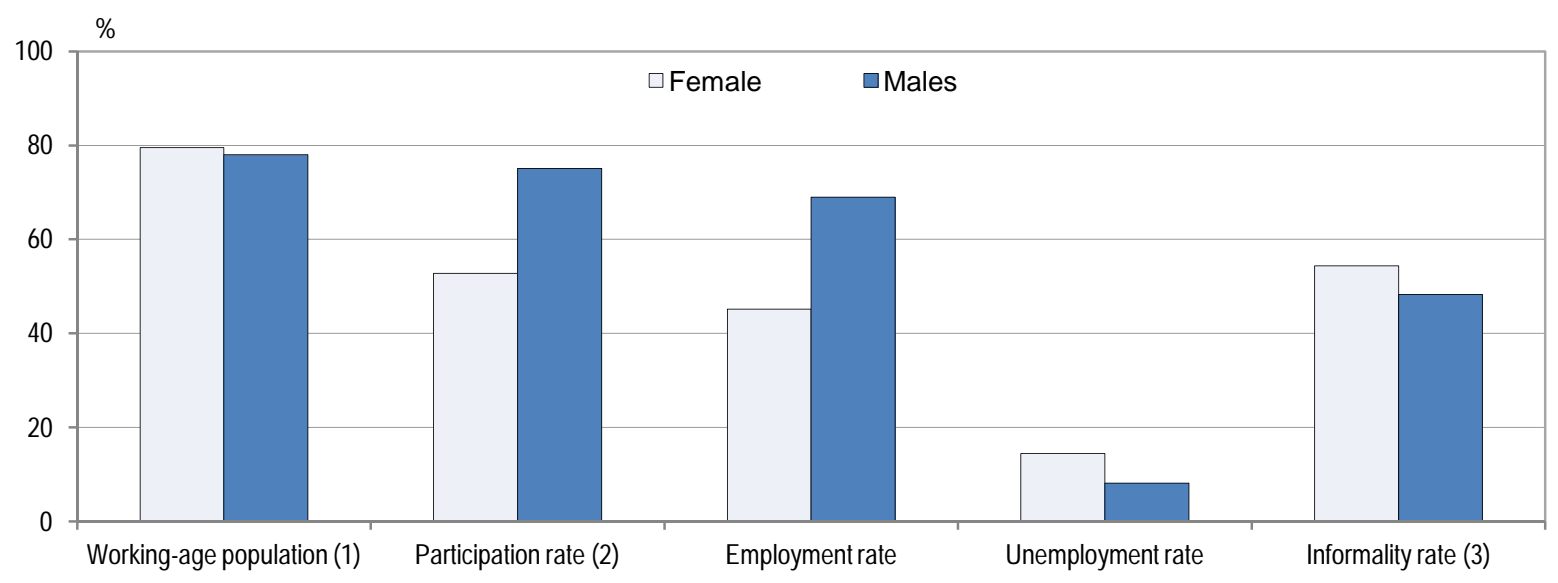

Panel B. The unexplained gender gap is higher at both extremes of the wage distribution ${ }^{4}$

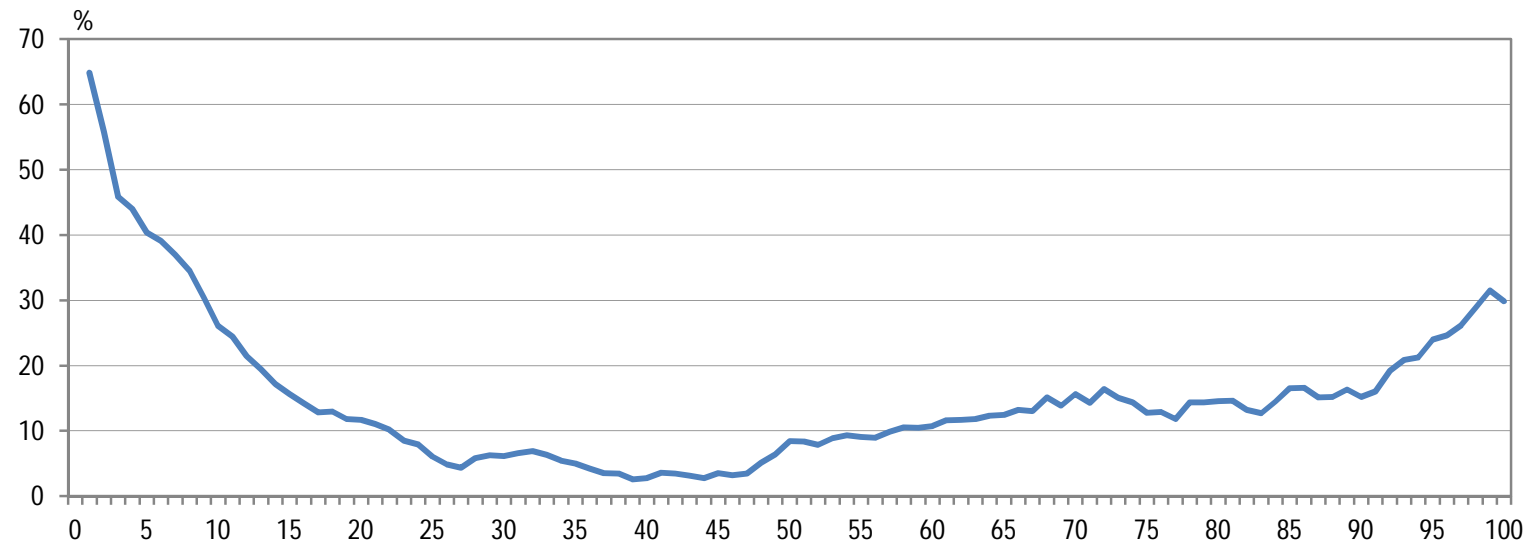

1. The working age population is defined as those aged above 12 in urban areas and above 10 in rural areas and is expressed as a share of total population.

2. The participation rate is defined as the share of the labour force to the working age population.

3. The informality rate is defined by the size of firms.

4. The figure depicts the unexplained gender wage gap by percentile of the wage distribution of males and females in 2002-2006. It uses non-parametric matching comparisons and controls for the full set of socio-demographic (e.g. age, education, marital status) and job-related characteristics (e.g. type of employer, formality, time worked, size of firm).

Source: DANE based on GEIH 2011; Hoyos et al. (2010) using household surveys 2002-2006.

Females earn on average $13 \%$ to $23 \%$ less than males, after controlling for labour market characteristics (Hoyos et al., 2010; Badel and Peña, 2010). The size of this gap is similar to averages in Latin America (Atal et al., 2010) and elsewhere (World Bank, 2011). The most penalised females are those at both extremes of the wage distribution (Fernández, 2006; Hoyos et al., 2010; Badel and Peña, 2010). The largest gaps are found among low-productivity individuals, i.e. those with less education, working part-time or in the informal sector (e.g. domestic servants). Given the over-representation of women in the 
informal sector, policies that tackle informality in the labour market will also reduce gender disparities. Wide gaps at the top of the distribution may partly reflect the lack of flexibility in working arrangements, which affect female participation in the labour market, but are also a clear sign of gender discrimination.

\section{Box 4. Policy recommendations to reduce labour income inequality}

Increasing the demand for labour in the formal sector by reducing labour costs

- $\quad$ Reduce the very high non-wage labour costs by implementing the planned tax reform and cutting further social security contributions and other mandatory payments on labour. Such cut should be financed by a move to less distortive taxes.

- $\quad$ Avoid increasing the minimum wage by more than price inflation. Consider differentiating the minimum wage by region and age to align labour costs with productivity and to account for differences in living costs.

- $\quad$ Remove the legal constraint on the minimum social security contribution base (currently a full-time minimum wage) to promote formal work, in particular for those with irregular income or part-time work.

- Redefine the mission and assess outcomes of SENA, ICBF and the Cajas and improve their costeffectiveness. Consider moving from mandatory to voluntary contributions to finance the commercial activities run by the Cajas.

- $\quad$ Ensure that the health coverage system does not create an incentive to remain in the informal sector, either by making the contributory and subsidised systems equally generous and guaranteeing those losing their formal job an immediate access to the subsidised system, or by unifying the contributory and subsidised systems.

Improving education and employment prospects for all

- Reinforce active labour market policies and introduce a Public Employment Service, as planned by the government.

\section{Improving education outcomes}

- $\quad$ Raise human capital by making the education and training system more responsive to the economy's needs and by increasing the quantity and quality of teaching. This would require reducing the prevalence of two- or even three-shift schools by investing in school infrastructure. This would also require reducing teacher absenteeism by introducing a monitoring system coupled with financial incentives. In the case of poor results, apply the recently introduced performance incentive system for teachers' remuneration, placement and firing more consistently. The quality of teaching should be improved by making the selection and training of teachers more demanding.

- Develop policies to recruit, train and retain quality teachers, especially in low-performing, disadvantaged schools. This could be supported by a scholarship programme to reduce costs for best performing, lowincome, future teachers.

- Pursue policies to improve the quality of teaching in the most deprived areas through mentoring programmes and by ensuring that teaching material is of high quality.

Improve equity in access to tertiary education

- The resources of the fund for student loans (ICETEX) should be increased and better targeted to those in need.

\section{Closing the gender gap}

- Implement policies to reduce informality and promote formal labour contracts so as to compress gender wage disparities.

- Increase flexibility in working arrangements to better reconcile work with family life, help break the glass ceiling effect, and reduce gender disparities at the top of the wage distribution. 


\section{BIBLIOGRAPHY}

Acción Social (2012), Reportes Generales Población Desplazada - Sistemas de Información para la Población Desplazada, http://www.accionsocial.gov.co/EstadisticasDesplazados/

Alm, J. and H. López-Castaño (2005), "Payroll Taxes in Colombia", Andrew Young School of Policy Studies, Working Paper, pp. 06-36.

Angulo R., J.P. Azevedo, A. Gaviria and G.N. Páez (2012), "Movilidad social en Colombia", (preliminary version), Report for the Mission on Equity and Social Mobility, DNP.

Attanasio, O., E. Battistin, E. Fitzsimons, A. Mesnard and M. Vera Hernández (2005), "How Effective are Conditional Cash Transfers? Evidence from Colombia", Briefing Note 54, Institute for Fiscal Studies, University College London.

Attanasio, O., E. Fitzsimons, S. Gratham-McGregor, C. Meghir and M. Rubio-Codina (2012), "Early Childhood Stimulation, Micronutrient Supplementation and Child Development: A Randomised Control Trial", Report for the Center for the Evaluation of Development Policies (EdePo) at Institute for Fiscal Studies (IFS), London, UK, April 30.

Badel, A. and X. Peña (2010), "Decomposing the Gender Wage Gap with Sample Selection Adjustment: Evidence from Colombia", Revista de Análisis Económico, 25(2): pp. 169-191.

Barón, J.D. and L. Bonilla (2011), "La calidad de los maestros en Colombia: Desempeño en exámen de Estado del ICFES y la probabilidad de graduarse en el área de educación", Banco de la República Documento de Trabajo sobre Economía Regional, No. 152, August.

Barrera-Osorio, F. and A. Corchuelo (2003), “SENA's Returns: A Re-evaluation”, Fedesarrollo Working Paper, July.

Barrera-Osorio, F., D. Maldonado and C. Rodríguez (2012), “Calidad de la Educación Básica y Media en Colombia : Diagnóstico y Propuestas", (preliminary version), Report for the Mission on Equity and Social Mobility, DNP.

Bassanini, A. and R. Duval (2006), "Employment Patterns in OECD countries: Reassessing the Role of Flows: A Cross-Country/Cross Industry Approach", OECD Social, Employment and Migration Working Papers, No. 107.

Bernal, R. S. (2009), “The Informal Labour Market in Colombia: Identification and Characterization”, Desarollo y Sociedad, 63: pp. 145-208.

Camacho, A., E. Conover and A. Hoyos (2009), "Effects of Colombia's Social Protection System on Workers' Choice between Formal and Informal Employment", Documento CEDE, No. 2009-18.

Carneiro, P. and J.J. Heckman (2003), "Human Capital Policy", in Inequality in America: What Role for Human Capital Policy? (eds. J. Heckman and A. Krueger), MIT Press, pp. 77-240.

CEDE. (2009), "Deserción en Educación Superior: Determinantes y Recomendaciones de Política", Notas de Politica, No. 1, University of Los Andes. 
Duflo, E., R. Hanna and S. P. Ryan (2012), "Incentives Work: Getting Teachers to Come to School”, American Economic Review, 102(4): pp. 1241-78.

Garay, L.J. (2008), "Proceso Nacional de Verificación de los Derechos de la Población Desplazada", First report to the Colombian Constitutional Court, Bogotá, Colombia.

Fernández, M. (2006), "Determinantes del Diferencial Salarial por Género en Colombia, 1997-2003", Desarrollo y Sociedad, 58: pp. 165-208.

Fernández, M., A.M. Ibáñez and X. Peña (2011). “Adjusting the Labour Supply to Mitigate Violent Shocks: Evidence from Rural Colombia”, World Bank Working Paper Series, No. 5684.

Ferreira, F.H. and J. Gignoux (2011), "The Measurement of Educational Inequality - Achievement and Opportunity”, World Bank Policy Research Working Paper, No. 5873.

Heckman, J.J. (2008), “The Case for Investing in Disadvantaged Young Children”, CESifo DICE Report, Ifo Institute for Economic Research at the University of Munich, 6(2): pp. 3-8, July.

Hoeller, P., I. Joumard, M. Pisu and D. Bloch (2012), "Less Income Inequality and More Growth - Are They Compatible? Part 1. Mapping Income Inequality Across the OECD", OECD Economics Department Working Paper, No. 924, OECD publishing, Paris.

Hofstetter, M. (2006), "La política Monetaria y la Corte Constitucional: El Caso del Salario Mínimo", Revista de Economía Institucional, 8(14): pp. 105-124.

Hoyos, A., H. Ñopo and X. Peña (2010), “The Persistent Gender Earnings Gap in Colombia, 1994-2006”, Documentos CEDE 2010-16.

Ibáñez, A.M. and A. Moya (2009a), "Vulnerability of Victims of Civil Conflicts: Empirical Evidence for the Displaced Population in Colombia", World Development, 38(4): pp. 647-663.

Ibáñez, A.M and A. Moya (2009b), "Do Conflicts Create Poverty Traps? Asset Losses and Recovery for Displaced Households in Colombia", in The Economics of Crime (eds. Rafael Di Tella, Sebastián Edwards and Ernesto Schargrodsky), University of Chicago Press.

Ibáñez, A.M. and A. Velásquez (2009), "Identifying Victims of Civil Conflicts: An Evaluation of Forced Displaced Households in Colombia", Journal of Peace Research, 42: pp. 431-451.

ILO (2011), "Statistical Update on Employment in the Informal Sector", ILO Department of Statistics, June.

IMF (2011), "Revenue Mobilization in Developing Countries", IMF Policy Paper prepared by the Fiscal Affairs Department, March.

Jorratt, M. (2010), "Diagnóstico de la Estructura Tributaria de Colombia y Propuesta de Reforma Tributaria", Report for the Inter-American Development Bank, July.

Joumard I. and J. Londoño Velez (2013), "Income Inequality and Poverty in Colombia. Part 2. The Redistributive Impact of Taxes and Transfers", OECD Economics Department Working Papers, No. 1037, OECD Publishing, Paris. 
Koske I., J.-M. Fournier and I. Wanner (2012), "Less Income Inequality and More Growth - Are They Compatible? Part 2. The Distribution of Labour Income", OECD Economics Department Working Paper, No. 925, OECD Publishing, Paris.

López-Calva, L.F. and N. Lustig (2010), Declining Inequality in Latin America: A Decade of Progress? Brookings Institution Press.

Moller, L.C. (2012), "Fiscal Policy in Colombia: Tapping its Potential For a More Equitable Society", The World Bank Policy Research Working Paper, No. 6092.

Mondragón-Vélez, C., X. Peña and D. Wills (2010), "Labour Market Rigidities and Informality in Colombia”, Journal of LACEA, Economía, 11(1): pp. 65-101.

OECD (2010), “A Family Affair: Intergenerational Social Mobility across OECD countries”, in Going for Growth, 2010 edition, OECD Publishing, Paris.

OECD (2012a), "Reducing Income Inequality while Boosting Economic Growth: Can It Be Done?" in Going for Growth, 2012 edition, OECD Publishing, Paris.

OECD (2012b), Tertiary Education in Colombia, Reviews of National Policies for Education, OECD Publishing, Paris.

OECD (2012c), Equity and Quality in Education - Supporting Disadvantaged Students and Schools, OECD Publishing, Paris.

Pisu, M. (2012), "Less Income Inequality and More Growth - Are They Compatible? Part 5. Poverty in OECD countries", OECD Economics Department Working Paper, No. 928, OECD Publishing, Paris.

Saavedra, J.E. and C. Medina (2012), "Formación para el Trabajo en Colombia", Documentos CEDE, 2012-35.

Sánchez Torres, F. and O. Alvarez Vos (2011), "La Informalidad Laboural y los Costos Labourales en Colombia 1984-2009 - Diagnóstico y Propuestas de Política”, Documentos CEDE, 2011-36.

Santamaría, M., F. García and A.V. Mujica (2009), "Los Costos No Labourales y el Mercado Laboural: El Impacto de la Reforma de Salud en Colombia", Fedesarrollo Working Paper No. 43, August.

Santamaría, M., R. Steiner, J.H. Botero, M. Martinez, N. Millan, M. A. Arias and E. Schutt (2010), “El Sistema Pensional en Colombia: Retos y Alternativas para Aumentar la Cobertura" (final report), Fedesarollo.

Sen, A. (1983), “Development, Which Way Now?”, The Economic Journal, 93(372): pp. 745-762, December.

Stiglitz, J.E., A. Sen and J.P. Fitoussi (2009), Report by the Commission on the Measurement of Economic Performance and Social Progress.

World Bank (2011), World Development Report 2012: Gender Equality and Development,

Washington D.C. 


\section{WORKING PAPERS}

The full series of Economics Department Working Papers can be consulted at www.oecd.org/eco/workingpapers/

1035. Policy options to durably resolve euro area imbalances

(March 2013) by Yvan Guillemette and Dave Turner

1034. Labour market, welfare reform and inequality in the United Kingdom

(March 2013) by Christophe André, Clara Garcia, Giulia Giupponi and Jon Kristian Pareliussen

1033. Work incentives and Universal Credit - reform of the benefit system in the United Kingdom (March 2013) by Jon Kristian Pareliussen

1032. Strengthening social cohesion in Luxembourg: making efficiency and equity go hand in hand (March 2013) by Jean-Marc Fournier and Clara Garcia

1031. The price of oil - Will it start rising again?

(March 2013) by Jean-Marc Fournier, Isabell Koske, Isabelle Wanner and Vera Zipperer

1030. The system of revenue sharing and fiscal transfers in China

(February 2013) by Xiao Wang and Richard Herd

1029. The declining competitiveness of French firms reflects a generalised supply-side problem (February 2013) by Hervé Boulhol and Patrizio Sicari

1028. Do the overall level and dispersion of socio-economic background measures explain France's gap in PISA scores?

(February 2013 by Hervé Boulhol and Patrizio Sicari

1027. Labour market performance by age groups: a focus on France

(February 2013) by Hervé Boulhol and Patrizio Sicari

1026. Moving towards a single labour contract: pros, cons and mixed feelings

(February 2013) by Nicolas Lepage-Saucier, Juliette Schleich and Etienne Wasmer

1025. Boosting productivity in Australia

(January 2013) by Vassiliki Koutsogeorgopoulou and Omar Barbiero

1024. Housing, financial and capital taxation policies to ensure robust growth in Sweden

(January 2013) by Müge Adalet McGowan

1023. Labour market and social policies to foster more inclusive growth in Sweden

(January 2013) by Stéphanie Jamet, Thomas Chalaux and Vincent Koen

1022. Educational attainment and labour market outcomes in South Africa, 1994-2010 (January 2013) by Nicola Branson and Murray Leibbrandt

1021. Education quality and labour market outcomes in South Africa (January 2013) by Nicola Branson and Murray Leibbrandt 
1020. Do policies that reduce unemployment raise its volatility? Evidence from OECD countries (January 2013) by Alain de Serres and Fabrice Murtin

1019. Slovakia: A catching up euro area member in and out of the crisis (January 2013) by Jarko Fidrmuc, Caroline Klein, Robert Price and Andreas Wörgötter

1018. Improving the fiscal framework to enhance growth in an era of fiscal consolidation in Slovakia (January 2013) by Caroline Klein, Robert Price and Andreas Wörgötter

1017. Investing efficiently in education and active labour market policies in Slovakia (January 2013) by Caroline Klein

1016. The performance of road transport infrastructure and its links to policies (January 2013) by Henrik Braconier, Mauro Pisu and Debra Bloch

1015. The US labour market recovery following the great recession (January 2013) by Wendy Dunn

1014. Why do Russian firms use fixed-term and agency work contracts? (December 2012) by Larisa Smirnykh and Andreas Wörgötter

1013. The Equity implications of fiscal consolidation (December 2012) by Lukasz Rawdanowicz, Eckhard Wurzel and Ane Kathrine Christensen

1012. The Dutch labour market: preparing for the future (December 2012) by Mathijs Gerritsen and Jens Høj

1011. Reforming policies for the business sector to harvest the benefits of globalisation in the Netherlands (December 2012) by Mathijs Gerritsen and Jens Høj

1010. Health care reform and long-term care in the Netherlands (December 2012) by Erik Schut, Stéphane Sorbe and Jens Høj

1009. Enhancing the inclusiveness of the labour market in Belgium (December 2012) by Jens Høj

1008. Reducing poverty in Estonia through activation and better targeting (December 2012) by Sarah Flèche and Artur Radziwill

1007. Matching skills and jobs in Estonia (December 2012) by Lilas Demmou

1006. Debt and macroeconomic stability: An overview of the literature and some empirics (December 2012) by Douglas Sutherland and Peter Hoeller

1005. Debt and macroeconomic stability: Debt and the business cycle (December 2012) by Volker Ziemann

1004. Debt and macroeconomic stability: Case studies (December 2012) by Rossana Merola 